\title{
THE ROLE OF NATURAL CLAYS IN THE SUSTAINABILITY OF LANDFILL LINERS
}

\author{
Mercedes Regadío ${ }^{1, *}$, Jonathan A. Black ${ }^{2}$ and Steven F. Thornton ${ }^{1}$ \\ ${ }^{1}$ Groundwater Protection and Restoration Group, Department of Civil and Structural Engineering, University of Sheffield, Broad Lane, \\ Sheffield, S3 7HQ, United Kingdom \\ ${ }^{2}$ Geotechnical Engineering Group, Department of Civil and Structural Engineering, University of Sheffield, Mappin Street, Sheffield, S1 \\ 3JD, United Kingdom
}

Article Info:

Received:

26 November 2019

Revised:

12 March 2020

Accepted:

27 April 2020

Available online:

8 May 2020

Keywords:

Chemical compatibility

Compacted clays

Attenuation

Landfill liners

Leachate pollutants

\begin{abstract}
Engineered synthetic liners on their own cannot protect the environment and human health against landfill leachate pollution. Despite their initial impermeability, they are susceptible to failure during and after installation and have no attenuation properties. Conversely, natural clay liners can attenuate leachate pollutants by sorption, redox transformations, biodegradation, precipitation, and filtration, decreasing the pollutant flux. Depending on the clay, significant differences exist in their shrinkage potential, sorption capacity, erosion resistance and permeability to fluids, which affects the suitability and performance of the potential clay liner. Here, the physico-chemical, mineralogical and geotechnical characteristics of four natural clayey substrata were compared to discuss their feasibility as landfill liners. To study their chemical compatibility with leachate and rainwater, hydraulic conductivities were measured every $\approx 2$ days spread over 7 weeks of centrifugation at 25 gravities. At field-scale, this is equivalent to every 3.4 yrs spread over $80 \mathrm{yrs}$. All the clayey substrata had favourable properties for the attenuation of leachate pollutants, although different management options should be applied for each one. London Clay (smectite-rich) is the best material based on the sorption capacity, hydraulic conductivity and low erodibility, but has the greatest susceptibility to excessive shrinkage and alterable clay minerals that partially collapse to illitic structures. Oxford Clay (illite rich) is the best material for buffering acid leachates and supporting degradation of organic compounds. The Coal Measures Clays (kaoline-rich) have the lowest sorption capacity, but also the lowest plasticity and have the most resistant clay minerals to alteration by leachate exposure.
\end{abstract}

\section{INTRODUCTION}

Leachates produced in municipal landfills constitute a health and environmental problem due to the different pollutants they content. For this reason, liners are required to minimise offsite migration of leachate. Two types of liners are currently used in modern landfills: synthetic liners, typically made of HDPE, and natural liners, typically made of compacted clay (Adar and Bilgili, 2015; Wei et al., 2018). Synthetic liners offer long-term impermeability to leachate but imply a high technology input and can be affected by slope stability, interface shear strength (Kavazanjian et al., 2006) and physico-chemical, thermal and mechanical problems (Kong et al., 2017), which may result in failure within 10 yrs of service (Rowe and Sangam, 2002; Rowe et al., 2003). Compacted clay liners are puncture-resistant and have advantageous reactive properties, but can be unstable in contact with leachate and susceptible to crack- ing under repeated wetting and drying cycles (Louati et al., 2018; Yesiller et al., 2000).

Because containment liners eventually fail independently of their low permeability properties, landfills are potential "ticking time bombs" that store and isolate waste until the confined pollutants are accidentally released to the environment in leachate. However, the intrinsic reactive properties of clays means they can biogeochemically interact with pollutants in leachates to decrease their availability and potential hazards over time. This reactivity (or attenuation) is enhanced if rainwater is allowed to enter the waste because then waste degradation is boosted, which accelerates its stabilization (Allen, 2001). The attenuation capacity of natural liners results in shorter periods of (1) potential release of pollutants and (2) aftercare monitoring, with subsequently lower landfill cost and less risk of environmental contamination. However, most attention has traditionally 
focused on the impermeability properties of liners as a performance characteristic. Here we focus on both impermeability and attenuation capacities, without relying solely on the impermeability (or containment) role, as a basis to improve liner design and performance. This dual capability can in principle be included in the engineering design of compacted clay liners to manage both organic and inorganic pollutants in leachate (Thornton et al., 1993; 1997).

The attenuation capacity, low cost and ease of implementation of compacted clay liners makes them more attractive than synthetic geomembranes on their own in landfill liner systems. This is particularly important in low-income countries where $>90 \%$ of waste is openly dumped (Kaza et al., 2018), and in removing organic pollutants (Beaven et al., 2009). However, clays are very diverse in their physico-chemical properties and the suitability of the clayey substratum as a potential liner must be properly evaluated (Widomski et al., 2018). This task is complex and, in order to avoid any adverse effects, must consider the factors and the interactions between them, which affect leachate-liner system. There are many factors involved, such as liner mineralogy, shrink/swell potential, sorption capacity, dispersive/erosion behaviour and fluid permeability. If the clay plasticity is too high, construction of the liner becomes more difficult and the swelling/shrinking/cracking potential more significant as a failure mechanism.

In this study, the feasibility of four natural clayey substrata as landfill liners was evaluated. Their physico-chemical, mineralogical and geotechnical characteristics were studied and the results were discussed in terms of strengths and weaknesses as candidate materials for landfill liners. Finally, the potential for attenuation of pollutants in leachate by each material was evaluated for sustainable landfill applications. The aim was to characterise the relevant properties of the different clays in order to identify those which are geotechnical stable and effective in pollutant attenuation for liner design. This is essential to prevent pollution of the environment and protect human health from leachate spreading over groundwater aquifers or adjacent rivers and lands.

\section{MATERIALS AND METHODS}

\subsection{Materials}

Four clayey substrata from the United Kingdom were studied: London Clay (LC), Oxford Clay (OC), and shallow and deep Coal Measures Clays (SCMC and DCMC) (Table
1). The LC originated from shale, greensand, chalk, and lateritic soils during a sea level rise over the Northern Sea Basin. It is a silty to very silty clay, slightly calcareous with disseminated pyrite. The OC, collected from the Peterborough Member, contained many visible fossils (vertebrate and invertebrate), particularly bivalves (Meleagrinella). In contrast to the two previous clays, the Coal Measures Clays originated in a fluvio-deltaic environment and also have a relatively high proportion of iron sulphides (pyrite, marcasite) and gypsum, the latter following pyrite weathering. These Coal Measures Clays consist of interbedded clay, shales, silt and sand, interstratified with coal.

Approximately $100,73,25$ and $20 \mathrm{~kg}$ of respectively LC, OC, SCMC and DCMC were recovered in-situ between June and July 2018. The pore water and cation exchange complex compositions were analysed in several subsamples before oven drying. The exchangeable cations were analysed in air-dried and powder samples (prepared with agate mortar and pestle) after applying 3 cycles of $10 \mathrm{sec}$ of ultrasonification to a suspension of $0.15 \mathrm{mg}$ clay in 50 $\mathrm{mL}$ deionized water. The elemental composition and mineralogy were determined after oven drying and grinding to a fine powder. For geotechnical tests the conglomerates were oven dried to remove residual moisture and the dry lumps broken up until a particle size $<0.2 \mathrm{~cm}$ was achieved. For this, a rammer and several perforated screen trays fitted in a CONTROLS sieve shaker (Model 15 d040/a1) were used and the clays first reduced into approximately $2 \mathrm{~cm}$ aggregate lumps. Next, the $<0.2 \mathrm{~cm}$ particles were recovered separately and the $0.2-2 \mathrm{~cm}$ lumps put into a bench soil grinder (Humboldt Co) and broken up to achieve $<0.2 \mathrm{~cm}$ size. All results are expressed as a function of dry mass.

\subsection{Analyses}

The concentrations of nitrogen, carbon, hydrogen and sulphur were analysed in duplicate samples ground to $\leq 0.1$ cm $(0.005 \mathrm{~g})$ using a Thermo Scientific FLASH 2000 Elemental Analyzer (CHNS). The remaining elements except oxygen and the halogens were analysed using a SpectroCiros-Vision radial ICP-OES instrument after acid digestion of 0.031 and $0.094 \mathrm{~g}$ at $150^{\circ} \mathrm{C}$. For this, $12 \mathrm{~mL}$ of aqua regia was applied for 30 min followed by two $1 \mathrm{~mL}$ volumes of $\mathrm{HF}$ for $10 \mathrm{~min}$, and the resulting solution was eluted up to $50 \mathrm{~mL}$ with 1 mass $\% \mathrm{HNO}_{3}$. The mineralogy was determined by X-ray diffraction (XRD) using a Ni-filtered Cu Ka radiation ( $k=0.15406 \mathrm{~nm}$ ) in a Philips X'Pert diffractometer,

TABLE 1: Information about the natural clayey substrata samples.

\begin{tabular}{|c|c|c|c|c|}
\hline & London Clay (LC) & $\begin{array}{l}\text { Oxford Clay from Peterborough } \\
\text { Member (OC) }\end{array}$ & $\begin{array}{l}\text { Shallow Coal Measures Clay } \\
\text { (SCMC) }\end{array}$ & $\begin{array}{l}\text { Deep Coal Measures Clay } \\
\text { (DCMC) }\end{array}$ \\
\hline Location (UK) & North Essex & Northwest Buckinghamshire & $\begin{array}{l}\text { West Yorkshire, collected close } \\
\text { to the surface }\end{array}$ & $\begin{array}{l}\text { West Yorkshire, collected at a } \\
\text { greater depth }\end{array}$ \\
\hline Age & $\begin{array}{l}\text { Eocene: } \\
47.8-56.0 \mathrm{Ma}\end{array}$ & $\begin{array}{l}\text { At the end of the Middle Juras- } \\
\text { sic: } 164-166 \mathrm{Ma}\end{array}$ & $\begin{array}{l}\text { Upper Carboniferous: } \\
310 \mathrm{Ma}\end{array}$ & $\begin{array}{l}\text { Upper Carboniferous: } \\
310 \mathrm{Ma}\end{array}$ \\
\hline Origin & Deep marine sediments & Deep marine sediments & Fluvio-deltaic sediments & Fluvio-deltaic sediments \\
\hline $\begin{array}{l}\text { Colour / } \\
\text { appearance }\end{array}$ & Uniform, firm, brown colour & $\begin{array}{l}\text { Grey colour with carbonaceous } \\
\text { shells and rootlets }\end{array}$ & Dark grey-dark brown colour & $\begin{array}{l}\text { Two-coloured: orange-light } \\
\text { brown and dark brown }\end{array}$ \\
\hline $\begin{array}{l}\text { Selected } \\
\text { references }\end{array}$ & $\begin{array}{l}\text { Fannin 2006; Kemp and Wagner, } \\
2006\end{array}$ & $\begin{array}{l}\text { Fannin 2006; Hudson and Mar- } \\
\text { till, 1994; Scotney et al., } 2012\end{array}$ & $\begin{array}{l}\text { Freeman, 1964, McEvoy et al., } \\
2016\end{array}$ & $\begin{array}{l}\text { Freeman, 1964, McEvoy et al., } \\
2016\end{array}$ \\
\hline
\end{tabular}


operating at $40 \mathrm{kV}$ and $40 \mathrm{~mA}$, with a step size of 0.016 and a speed of $2 \mathrm{~s} / \mathrm{step}$. The samples were prepared by both sprayed random powder (after grinding down to 1-3 $\mu \mathrm{m}$ ) and flat oriented slides (after obtaining the $<2-\mu \mathrm{m}$ fraction by dispersant and Stokes' law). Each oriented sample was prepared from a suspension of $0.1 \mathrm{~g}$ of the clay-fraction in $2 \mathrm{~mL}$ of a solution in three ways: (1) in water and air drying, (2) in water and $550^{\circ} \mathrm{C}$ drying for $2 \mathrm{~h}$, and (3) in a glycerol solution and air drying (Moore and Reynolds, 1997). The software PDF-4+ 2019 (version 4.19.0.1) and the database v. 4.1903 were used for data interpretation. The content of organic matter, sulphides, hydroxyl groups and carbonates phases was determined by termogravimetrical analysis (TGA). Replicates between $0.015-0.030 \mathrm{~g}$ were heated from 30 to $995^{\circ} \mathrm{C}$ at a rate of $20^{\circ} \mathrm{C} / \mathrm{min}$ with a TGA 4000 Perkin Elmer under two atmospheres: $\mathrm{N}_{2}$ and $\mathrm{O}_{2}$ gas (20 $\mathrm{mL} / \mathrm{min}$ ). The results were interpreted in combination with the CHNS, ICP-OES and XRD results. The external specific surface area was measured in 0.2-0.5 g of degassed material $\left(60^{\circ} \mathrm{C}\right)$ by the Brunauer-Emmett-Teller (BET) method of nitrogen gas sorption at $77 \mathrm{~K}$ in both a Micromeritics Tristar II 3020 and Beckman Coulter SA-3100. The material was prepared from $1 \mathrm{~g}$ of original sample gently ground to $<400 \mu \mathrm{m}$ (at least 10 cycles) and discarding the fraction below $64 \mu \mathrm{m}$ (Bertier et al., 2016). The particle size distribution as volume percent was determined by the Malvern Mastersizer $3000^{\circledR}$ (double) Laser Diffraction (software version 3.62) assuming the refractive index and density of silica $\mathrm{SIO}_{2}$ (respectively 1.457 and $2.65 \mathrm{~g} / \mathrm{cm}^{3}$ ). Samples were dispersed in distilled water by stirring at $2500 \mathrm{rpm}$ and ultrasonic treatment. Measurements of 10 min duration were repeated in the same sample until the results were constant and an average taken.

The pore water chemistry was obtained by mixing 20 $\mathrm{mL}$ of deionized water to $10 \mathrm{~g}$ of wet clay at room temperature. Sample $\mathrm{pH}$ was measured with a $\mathrm{pH}$ glass electrode in the water:clay mixture after settling for $24 \mathrm{~h}$ and shaking prior to the analysis. The solution was then centrifuged and filtered $(0.45 \mu \mathrm{m})$ to measure the electrical conductivity with a $0.4-\mathrm{cm}$ sensor, and the soluble elements. The soluble anions and cations were analysed by ion chromatography (Dionex ICS-3000), the alkalinity by titration with $\mathrm{H}_{2} \mathrm{SO}_{4}$ (HACH digital titrator) and the carbon soluble species using a TOC-V-CSH analyser (Shimadzu ASI-V). The cations in the exchange complex were determined as the difference between the cations extracted with a $1.26 \mathrm{M}$ $\mathrm{SrCl}_{2}$ solution $(80 \mathrm{~mL})$ minus the soluble fraction extracted with water $(80 \mathrm{~mL})$ after shaking with $5 \mathrm{~g}$ of clay for 10 minutes (Edmeades and Clinton, 1981). Due to the high ionic strength of the $\mathrm{SrCl}_{2}$ solutions, sodium, potassium, calcium and magnesium in these extracts were analysed by atomic absorption spectroscopy, AAS (HITACHI Polarized Zeeman Z2300), whereas ammonium was analysed by atomic emission spectroscopy. $\mathrm{LaCl}_{3}$ was added at $20 \%$ to standards and samples for the AAS analyses of calcium and magnesium. The cation-exchange capacity (CEC) was determined by copper complex with Cu-triethylenetetramine at $\mathrm{pH} 7-8$, with a photometer at a wavelength for maximum extension of $579 \mathrm{~nm}$ (Holden et al., 2012; Stanjek and Künkel, 2016).
To study the consistency and engineering behaviour of the materials, the clay samples were hydrated with different amounts of water for 24 hours in sealed plastic bags prior to index property tests (Head, 2006). The consistency was studied in the $<425-\mu \mathrm{m}$ fraction $(250 \mathrm{~g})$ by the determination of two specific water (or moisture) contents: the liquid limit, LL (water content that separates the plastic and liquid states) and the plastic limit, PL (water content that separates the semi-solid and plastic states). The change of clay consistency from plastic to liquid state was determined by the free-falling cone test at a penetration of $2 \mathrm{~cm}$ into the wet sample, with duplicates differing $\leq 0.05$ cm (BS 1377:2:4.3, 1990). The change of clay consistency from semi-solid to plastic state was determined by manual rolling wet samples $(20 \mathrm{~g})$ until threads of $0.3-\mathrm{cm}$ diameter begin to crumble, with four replicates differing $\leq 2 \%$ moisture content of their PL (BS 1377:2:5.3, 1990 and ASTM D $4318,2015)$. To know the range of water content in which the clayey material has a plastic consistency, the plasticity index $(\mathrm{PI})$ was calculated as the difference between the $\mathrm{LL}$ and the PL (Head, 2006). All actual moisture contents were determined on a mass \% dry basis (Equation 1) after oven drying $5-10 \mathrm{~g}$ of material $\left(105^{\circ} \mathrm{C}, 48 \mathrm{~h}\right)$ with duplicates that differ $\leq 0.5 \%$.

$\operatorname{MC}(\%)=\frac{m_{0}-m_{d}}{m_{d}} \times 100=\frac{m_{0, c}-m_{d, c}}{m_{d, c}-m_{c}} \times 100$

where $\mathrm{MC}$ is the moisture content dry basis (\%), $\mathrm{m}_{0}$ is the mass of wet sample before moisture removal $(\mathrm{g}), \mathrm{m}_{\mathrm{d}}$ is the mass of sample after drying $(\mathrm{g}), \mathrm{m}_{0, \mathrm{c}}$ is the mass of wet sample plus container before moisture removal $(\mathrm{g}), \mathrm{m}_{\mathrm{d}, \mathrm{c}}$ is the mass of sample plus container after drying $(\mathrm{g})$ and $\mathrm{m}_{\mathrm{c}}$ is the mass of the container $(\mathrm{g})$.

The optimal condition of the clays at which the susceptibility to settlement is reduced was studied by applying the same compactive effort in different hydrated samples (240-540 mL water in 1600-1800 g clays). The compaction was placed into a mould of $5.25 \mathrm{~cm}$ radius by $11.55 \mathrm{~cm}$ height, in three equal layers subjected to 27 blows each one, by a $2.5 \mathrm{~kg}$ rammer of $2.5-\mathrm{cm}$ radius that dropped from a height of $30 \mathrm{~cm}$ (BS 1377:4:3.3, 1990). The optimum moisture content (OMC) was selected on the basis of the maximum dry (bulk) density (MDD) after the compaction. To calculate the particle density of the solids, the specific gravity $\left(\mathrm{G}_{\mathrm{s}}\right.$ ) was obtained by triplicate tests at $20^{\circ} \mathrm{C}$, in desiccated materials of $<0.2 \mathrm{~cm}$ size $(50 \mathrm{~g})$ using air-dried pycnometers of $50 \mathrm{~mL}$ (BS 1377:2:8.3, 1990 but $20^{\circ} \mathrm{C}$ instead of $25^{\circ} \mathrm{C}$ ). The porosity (n) was calculated as a percentage following Equation 2 (Equation 3 for the optimal conditions). The slight difference between $\mathrm{n}$ and void ratio (e) is that the latter measures the void volume (the sum of $\mathrm{V}_{\text {air }}$ and $\mathrm{V}_{\mathrm{w}}$ ) in relation to the volume of the solid instead of the total volume. Thus, e (normally expressed as a ratio) can be $>1$, but $n$ cannot be higher than $100 \%$.

$$
\begin{aligned}
& n(\%)=\frac{V_{a i r}+V_{w}}{V_{T}} \times 100=\frac{V_{T}-V_{S}}{V_{T}} \times 100 \\
& n_{\text {opt }}(\%)=\frac{V_{T}-\frac{m_{d, O M C}}{G_{S}}}{V_{T}} \times 100
\end{aligned}
$$

where $V_{\text {air }}$ is the volume of the air $(\mathrm{mL}), \mathrm{V}_{\mathrm{w}}$ is the volume of the water $(\mathrm{mL}), \mathrm{V}_{\mathrm{T}}$ is the total volume (mould of $1000 \mathrm{~mL}$ ), 
$V_{s}$ is the volume of the solid particles $(m L), m_{d, \text { omc }}$ is the dried mass of sample at the OMC (g) and $\mathrm{Gs}$ is the specific gravity (unitless).

Assuming that volumes of voids filled with air are constant $\left(\eta_{\text {air, }}\right)$, lines at different air void $\left(\eta_{\text {air, }, 1}, \eta_{\text {air, }} \ldots\right)$ and saturation values can be drawn as a function of dry bulk density $\left(\mathrm{Y}_{\mathrm{d}, \mathrm{i}}\right)$ relative to the moisture content ratio (Equation 4). The difference between air void line $\left(\eta_{\text {air }}\right)$ and saturation (s) is that the latter ratio measures the volume of water in relation to the void volume instead of the total volume. The zero-air void line $\left(\eta_{\text {air }}=0\right)$ corresponds to the maximum saturation ratio $(s=1)$.

$\gamma_{d, i}=\frac{\left(1-\eta_{a i r, i}\right) \cdot G_{s} \cdot \gamma_{w}}{1+M C i \cdot G_{s}}$ being $\eta_{a i r, i}=\frac{V_{a i r, i}}{V_{T}}$

where $\mathrm{Y}_{\mathrm{d}, \mathrm{i}}$ and $M \mathrm{C}_{\mathrm{i}}$ are the dry bulk densities $\left(\mathrm{g} / \mathrm{cm}^{3}\right)$ and the moisture contents (ratio) corresponding to the air void constant $i, \eta_{\text {air, }}$ is the line corresponding to an air void and saturation constant i related to the total volume (ratio), $\mathrm{G}_{s}$ is the specific gravity (unitless) and $\gamma_{w}$ is the density of water $\left(1 \mathrm{~g} / \mathrm{cm}^{3}\right)$.

The specific value for the air void and saturation line after compaction at the optimal conditions $\left(\eta_{\text {airopt }}\right)$ was calculated with the $\mathrm{Y}_{\mathrm{d}, \mathrm{i}}$ and $\mathrm{MC}_{\mathrm{i}}$ equal to MDD and OMC (ratio), respectively (Equation 5 ).

$\eta_{\text {air opt }}(\%)=\left(1-\frac{M D D\left(1+O M C \cdot G_{S}\right)}{G_{S} \cdot \gamma_{w}}\right) \times 100$

The potential swell (S \%) was determined based on its relationship with the Atterberg limits by the well-defined empirical Equation 6 (Seed et al., 1962):

$\mathrm{S}(\%)=216 \cdot 10^{-5} \cdot \mathrm{PI}^{2.44}$

where $\mathrm{PI}$ is the plasticity index (\%).

The hydraulic conductivity or permeability coefficient (K) was measured in aluminium permeation cylinders by centrifuging at 25 gravities (Regadío et al., 2020). Model liners were compacted into of $5 \mathrm{~cm}$ radius by $10 \mathrm{~cm}$ height cylinders after being hydrated with tap water at the OMC. Leachate from a municipal solid waste landfill and rainwater were used as permeating fluids. Rainwater was normally used for permeating model liners previously permeated with landfill leachate. Eleven cylinders on average were assembled per centrifuge test, each one connected to an intake line. All intake lines came from a common tank that provided continuous permeation to all the cylinders by applying a pressure of $1.1 \mathrm{bar}$. The tests were conducted under a $50 \% \mathrm{CO}_{2} / \mathrm{N}_{2}$ anaerobic gas (for leachate permeation) or under compressed air (for rainwater permeation). The fluid head in the tank that provided the permeating fluid was measured every $\approx 2$ days during 2.5 weeks under leachate permeation, or 4.5 weeks under rainwater permeation. The $\mathrm{K}$ measured in the centrifugal permeability tests ("experimental model") had a 25 -fold enhanced gravity. To calculate the corresponding real value in the field ( $\mathrm{K}$ "prototype"), the scaling law ( $\mathrm{Ng}, 2014)$ was applied in the falling head equation for less permeable soils (Head, 1994) adapted to this method (Equation 7):

$K=\frac{K_{\text {exp.m }} \cdot n}{n^{2}}=\frac{\frac{a L}{A t} \ln \left(\frac{h_{0}}{h_{1}}\right)}{n}$, being $h_{1}=\frac{h_{0}-\left(h_{0}-h_{1 \#}\right)}{\#}$

where $K_{\text {exp. }}$ is the hydraulic conductivity in the experimental model $(\mathrm{m} / \mathrm{s}), \mathrm{n}$ is the enhanced gravity applied in the centrifugal experiment (25), a is the cross area of the tank $\left(0.06158 \mathrm{~m}^{2}\right), \mathrm{L}$ is the lengh of the liner specimen $(0.10000$ $\mathrm{m}), A$ is the cross area of the liner specimen $\left(0.00785 \mathrm{~m}^{2}\right), t$ is the time period considered for the calculation (seconds), $\mathrm{h}$ is the head in the tank at the initial (if subscript 0 ) and final (if subscript 1\#) points, \# is the number of model liners connected to the tank.

\section{RESULTS}

\subsection{Elemental composition and mineralogy}

The four clayey substratum were mainly composed of silicium and aluminium, followed by iron, potassium, hydrogen and magnesium (Figure 1). This agreed with the expected high presence of clay minerals, potentially higher in Coal Measures Clays (see below). Silica, potassium, titanium, and especially magnesium were higher in the LC. The OC was notable for its high content in calcium, carbon, sulphur $(\mathrm{g} / \mathrm{kg})$ and strontium $(\mathrm{mg} / \mathrm{kg})$, with lower silica, iron and phosphorus content. The Coal Measures Clays were notable for their high concentration of aluminium, nitrogen and manganese, whereas the concentration of calcium, sodium, potassium, strontium and boron were the lowest within the four samples. In the case of SCMC, there was more carbon, nitrogen and sulphur than in DCMC. (Figure 1).

All samples contain smectite, illite, kaolinite and chlorite but in different proportions (Figure 2). Smectite was most important in LC, illite together with kaolinite in OC, and kaolinite (followed by illite) in the Coal Measures Clays. To a lesser extent, phlogopite mica was detected in LC, chlorite in both LC and OC, and interstratification (mixture of layers) of illite/smectite in OC and the two Coal Measures Clays.

Quartz and feldspars were the most important phases in all materials. These are accompanied by oxides except in the $\mathrm{OC}$, which mainly contained calcium carbonate and iron sulphide (calcite and pyrite). Also relatively high levels of sulphides were found in SCMC, whereas, there were fluorides and oxide-fluoride in DCMC (Figure 3). The mass loss through heating due to dehydroxylation (associated with the mass of clay minerals) was the highest in the Coal Measures Clays (5-9\%), while the highest mass loss due to decomposition of organics, sulphides and carbonates phases corresponded to OC (2, 4 and $5 \%$ respectively). Particulate organic matter as an associated material in these clays was especially high in the OC. It varied from 1.1 to $3.5 \%$ in the OC, in contrast to LC, SCMC and DCMC, which gave steady values of $1.7,1.5$ and $1.8 \%$, respectively. The variability in the particulate organic matter content in the $\mathrm{OC}$ was due to its presence in many diverse forms: disseminated organic matter, coarse lignite fragments and fossils. Similarly, the carbonate phases in the OC varied from 4.5 to $6 \%$ due to the spread of carbonaceous shells.

\subsection{Pore water and mineral surface characteristics}

The LC had the highest natural moisture content followed by the OC (39 and $25 \pm 2 \%$, respectively), whereas SCMC and DCMC had the lowest values (10 and $12 \pm 1 \%$, respectively). This indicates a decreased water absorption and porosity from $\mathrm{LC}>\mathrm{OC}>\mathrm{Coal}$ Measures Clays. The pore water composition of the clayey materials of the OC was 

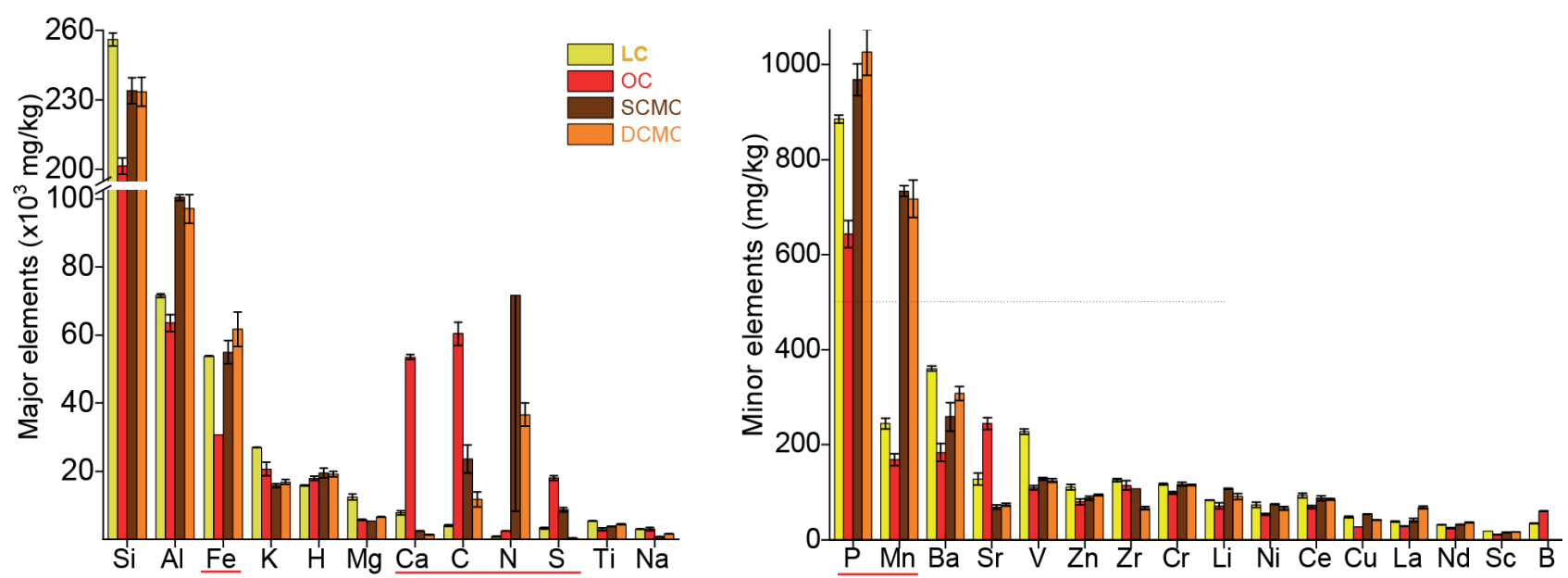

FIGURE 1: Elemental composition of London Clay (LC), Oxford Clay (OC), shallow Coal Measures Clay (SCMC) and deep Coal Measures Clay (DCMC).

the most basic due to the presence of calcium carbonate phases $(\mathrm{pH}$ 9.0) and the LC was close to neutral ( $\mathrm{pH} 7.3)$. In contrast, the SCMC and DCMC were acidic $(\mathrm{pH} 3.8$ and 5.4,

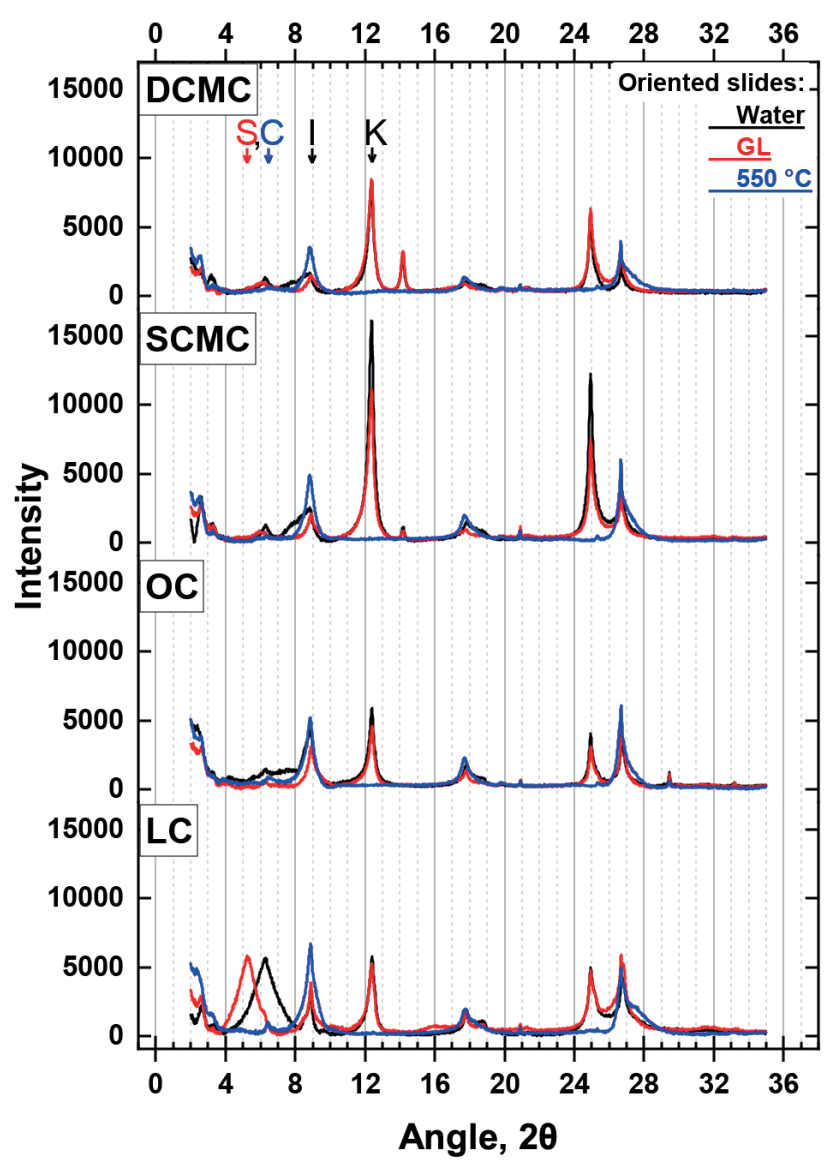

FIGURE 2: Sheet-silicate mineralogy of London Clay (LC), Oxford Clay (OC), shallow Coal Measures Clay (SCMC) and deep Coal Measures Clay (DCMC). Water: water and air drying preparation, GL: glycerol and air drying preparation, $550^{\circ} \mathrm{C}$ : water and $550^{\circ} \mathrm{C}$ drying preparation. S: smectite d001 reflection under GL preparation, C (chlorite) and I (illite) d001 reflections under all three preparations. K: kaolinite d001 reflection under water and GL preparations. respectively). Consistent with this, alkalinity was only present in the $\mathrm{OC}\left(10.3 \mathrm{mmol} / \mathrm{kg}\right.$ as $\left.\mathrm{CaCO}_{3}\right)$ and $\mathrm{LC}(1.7 \mathrm{mmol} /$ $\mathrm{kg}$ as $\mathrm{CaCO}_{3}$ ). The total dissolved ion content in terms of electrical conductivity in aqueous extracts (L/S 1:2.5) was between 1-3 mS/cm, except for DCMC $(0.1 \mathrm{mS} / \mathrm{cm})$ and for $\mathrm{OC}(5 \mathrm{mS} / \mathrm{cm})$. The predominant soluble anion in all samples was sulphate $\left(\mathrm{SO}_{4}{ }^{2-}\right)$, mainly balanced by calcium $\left(\mathrm{Ca}^{2+}\right)$ and sodium $\left(\mathrm{Na}^{+}\right)$in both the $\mathrm{LC}$ and $\mathrm{OC}$, by magnesium $\left(\mathrm{Mg}^{2+}\right)$ and $\mathrm{Ca}^{2+}$ in the SCMC and mostly $\mathrm{Na}^{+}$in the DCM. In all cases the concentration of potassium $\left(\mathrm{K}^{+}\right)$was very low and ammonium $\left(\mathrm{NH}_{4}^{+}\right)$was not detected. Only the $\mathrm{OC}$ had a significant content of soluble carbon in the pore water $(10 \mathrm{mg} / \mathrm{g})$.

As expected the exchangeable cations on the negatively charged sites of the clays and particulate organic matter were similar to the most abundant in the pore water. The sum of exchangeable cations often exceeded the total charge of the clay (CEC), due to high concentrations of $\mathrm{Ca}^{2+}$ released by dissolution of carbonate minerals. Thus, the CEC was measured directly instead of estimating this from the sum of exchangeable cations, to avoid bias from $\mathrm{Ca}^{2+}$. The CEC at $\mathrm{pH} 7-8$ decreased in the order: $\mathrm{LC}(26$ $\mathrm{cmol}+/ \mathrm{kg})>\mathrm{OC}(16 \mathrm{cmol}+/ \mathrm{kg})>$ Coal Measures Clays $(13$ $\mathrm{cmol}+/ \mathrm{kg})$. The external specific surface area increased in the order: $\mathrm{LC}<\mathrm{OC}<\mathrm{DCMC}<\operatorname{SCMC}(9.3 \pm 0.3,12.8 \pm 3.6$, $31.0 \pm 1.0,53.7 \pm 1.0 \mathrm{~m}^{2} / \mathrm{g}$, respectively). The highest values corresponded to the material with the highest amount of hydrous aluminium phyllosilicates minerals (Coal Measures Clays), followed by the material with the highest amount of particulate organic matter (OC). Nonetheless, the total surface area (external plus internal) of the LC may be one of the largest due to its higher content of expandable clay minerals (illite + smectite) than non-expandable ones (kaolinite + chlorite).

\subsection{Consistency classification and properties}

The moisture contents at PL and LL were determined to identify clays susceptible to dispersion and excessive shrinkage in the field (Table 2). These parameters can distinguish between silt- and clay- size, and organic or inor- 
510152025303540455055606570

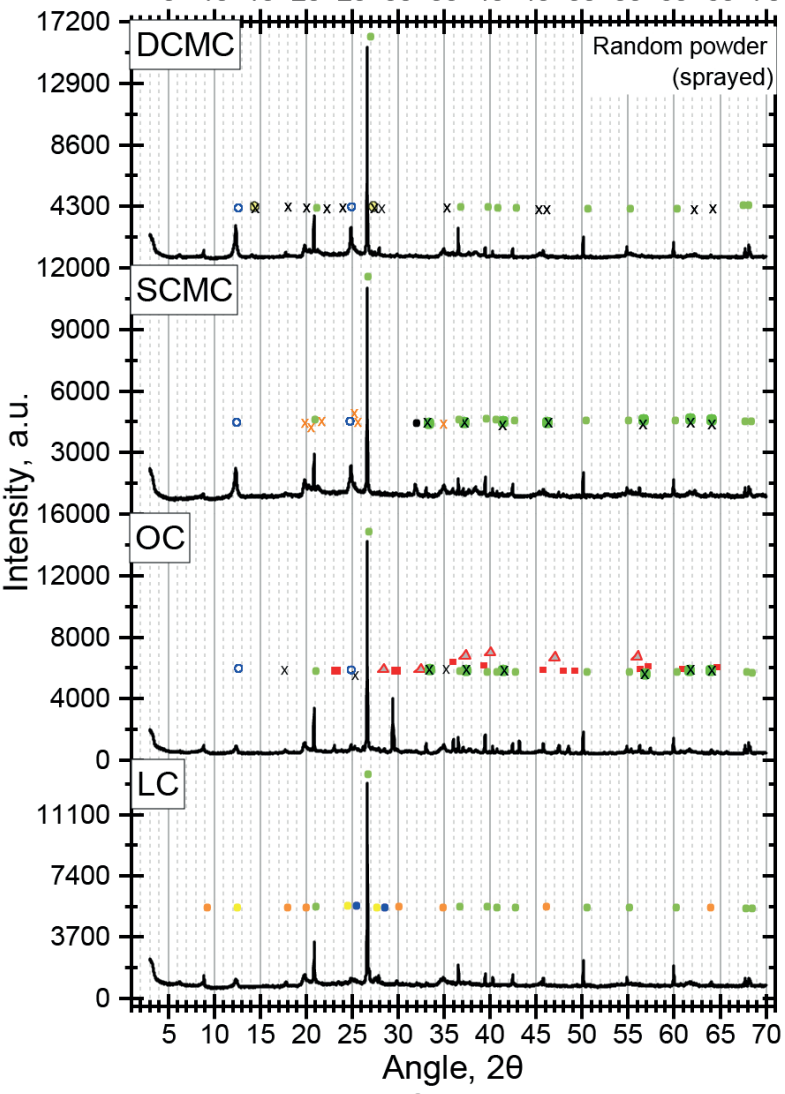

- $\mathrm{SiO}_{2},{ }^{\circ}$ Kaolinite, $\otimes \mathrm{y}-\mathrm{Fe}{ }^{3+} \mathrm{O}(\mathrm{OH}), x \mathrm{KNaAlFeSiO} \mathrm{O}_{4}$

$\times \mathrm{NaZnSiO}_{4}, \bullet \mathrm{AlPO}_{4}, \mathbf{x F e N d S}=, \mathrm{FeS},=\mathrm{CaCO}_{3}, \triangle \mathrm{FeS}_{2}$

- $\mathrm{KMgAISiO}_{4} \mathrm{OH}, \mathrm{BaMgAlSiO}_{4}, \cdot \mathrm{KCaAICrFeSiO}_{4} \mathrm{OH}$

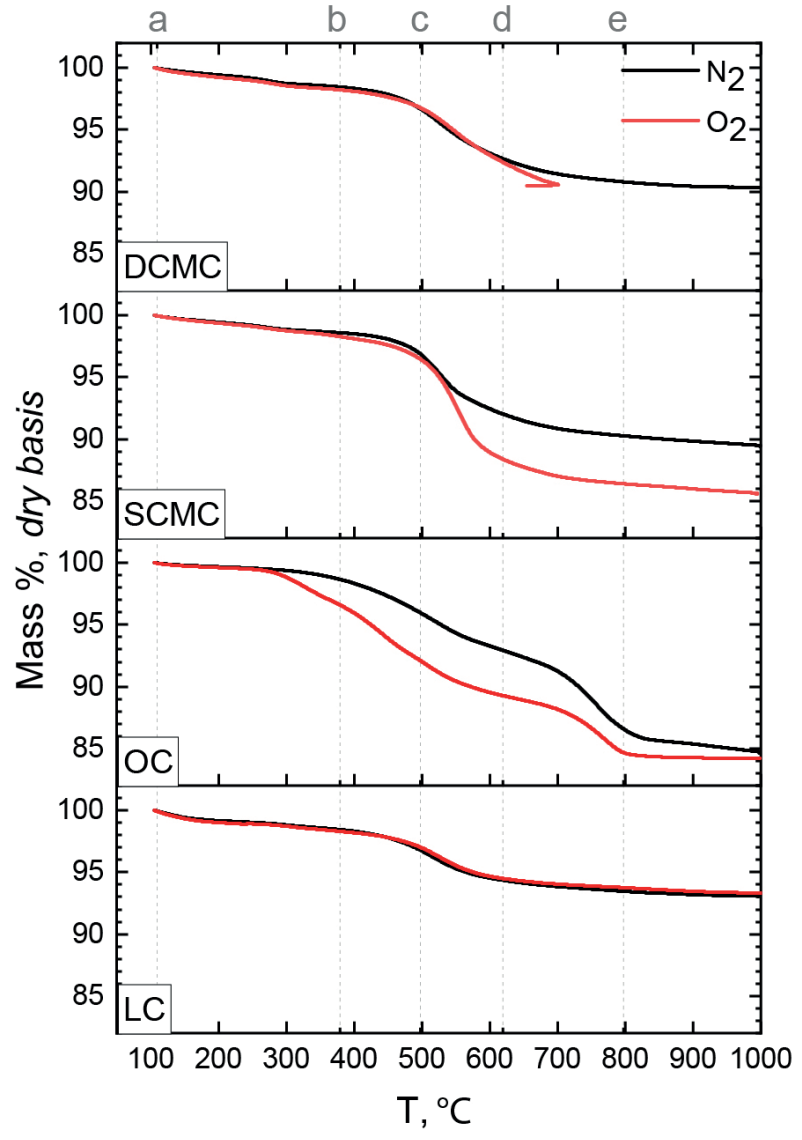

FIGURE 3: Left: Global mineralogy by sprayed random powder of London Clay (LC), Oxford Clay (OC), shallow Coal Measures Clay (SCMC) and deep Coal Measures Clay (DCMC). Right: TGA curves with mass relative to the mass after dehydration (removal of interlayer water): (a-b) mass loss mainly due to thermal decomposition of organic matter, (b-c) mass loss due to thermal decomposition of sulphides, (cd) mass loss due to dehydroxylation, (d-e) mass loss due to thermal decomposition of carbonate and (e-end) materials vitrification and formation of new phases (recrystallization).

ganic character. All clays had a LL $>20 \%$, confirming that they were cohesive materials. The LL and PI varied in the order: $\mathrm{LC}>\mathrm{OC}>$ Coal Measures Clays, consistent with the dominant sheet silicate in each material: smectite, illite/kaolinite and kaolinite, respectively. The LC and OC had high plasticity, high toughness and high to very high dry strength (Figure 4). The high plasticity of LC was notable for the broad range of water contents at which this clay had plastic consistency (from 28 to $79 \%$, i.e., $\mathrm{PI}=51 \%$ ), twice that of the OC. This is due to the presence of smectite (expandable clay mineral) and the higher content of clay-size particles in the LC compared with the other clays with a higher silt content. Ninety vol\% of the LC was composed of particles $\leq 52 \mu \mathrm{m}$, whereas 90 vol\% of the DCMC, SCMC and OC were made up of particles $\leq 130 \mu \mathrm{m}, \leq 136 \mu \mathrm{m}$ and $\leq 185 \mu \mathrm{m}$, respectively. The two Coal Measures Clays gave similar results: intermediate plasticity, medium toughness and high dry strength. The potential to swell decreased from LC >> OC > SCMC > DCMC $(30.2,5.3,2.6,2.4 \%)$, as expected from the mineralogy and PI results. All studied materials had no dispersive clay fines as these do not occur in clays from intermediate to high plasticity with smectite. On the con- trary, dispersive clays typically appear in soils classified as clayey of low plasticity (CL), sometimes also in silty and/or sandy soils with low plasticity (ML, CL-ML) (Figure 4).

The "A-line" on the plasticity chart (Figure 4) denotes the empirical boundary between inorganic materials and clays (above line) and organic clays and clastic silts (below line). The OC fell on the dividing line between inorganic and organic categories, while Coal Measures Clays and the LC fell above the line in the inorganic region, being the DCMC close to the organic silts, and the LC the most inorganic clay.

\subsection{Compaction and permeability behaviours}

Clays are normally compacted for placing and constructing the clay liners because to increase the shear strength and bearing capacity, which limits future settlement. In addition, the void ratio and permeability is decreased, and variations in volume change are less pronounced. Consequently, clays are less susceptible to cracking that would offer preferential flow paths for leachate leakage and groundwater seepage. To optimise this, clays should be compacted close to the OMC, the quantity of water nec- 
TABLE 2: Moisture contents corresponding to the Atterberg consistency limits (<425- $\mu$ m fraction).

\begin{tabular}{|c|c|c|c|c|c|c|}
\hline & \multicolumn{2}{|c|}{ Linear regression } & \multirow{2}{*}{ LL, \% } & \multicolumn{2}{|c|}{$\mathrm{PL}, \%$} & \multirow{2}{*}{$\begin{array}{l}\mathrm{PI}, \% \\
\text { Value }\end{array}$} \\
\hline & Slope & Intercept & & Value & RSD, percent & \\
\hline LC & 0.552 & -23.339 & 79 & 28 & 4.4 & 51 \\
\hline $\mathrm{OC}$ & 1.136 & -40.404 & 53 & 29 & 4.3 & 24 \\
\hline SCMC & 1.758 & -49.944 & 40 & 22 & 4.0 & 18 \\
\hline DCMC & 1.368 & -40.052 & 44 & 25 & 0.9 & 19 \\
\hline
\end{tabular}

Linear regression: relationship of the cone penetration ( $Y$-axis in $\mathrm{mm}$, as a reverse measure of the shear strength) on the moisture content (X-axis in \%), $L L$ (or WL): liquid limit, PL (or WP): plastic limit, PI (or Pi): Plasticity index, RSD: relative standard deviation (the standard deviation divided by the average and multiplied by 100), LC: London Clay, OC: Oxford Clay, SCMC: shallow Coal Measures Clay, DCMC: deep Coal Measures Clay.

essary to achieve the maximum dry (bulk) density. Under the same compaction effort, the OMC followed the order LC > OC > Coal Measures Clays, while the maximum dry (bulk) densities followed the inverse sequence (Figure 5). The clay sequence for OMC agreed with those for air void lines and for porosity (both after compaction at the optimal conditions), and with the higher plasticity of LC, followed by OC, which could accommodate more water to achieve their maximum dry densities than the Coal Measures Clays. The particle density of the solids, in terms of specific gravity, followed the order LC > Coal Measures Clays > OC due to the higher particulate organic matter content of the last one (Figure 5). Both Coal Measures Clays had very similar consistency and engineering behaviour (Figure 4 and Figure 5).

The $\mathrm{K}$ for leachate and rainwater through the most plastic clays (LC and OC) amended with sandy materials was measured over time. In all three tests run with landfill leachate, $\mathrm{K}$ slightly increased from initial values of 0.1 and $0.3 \cdot 10^{-9} \mathrm{~m} / \mathrm{s}$ to a maximum of 0.6 and $0.8 \cdot 10^{-9} \mathrm{~m} / \mathrm{s}$ after

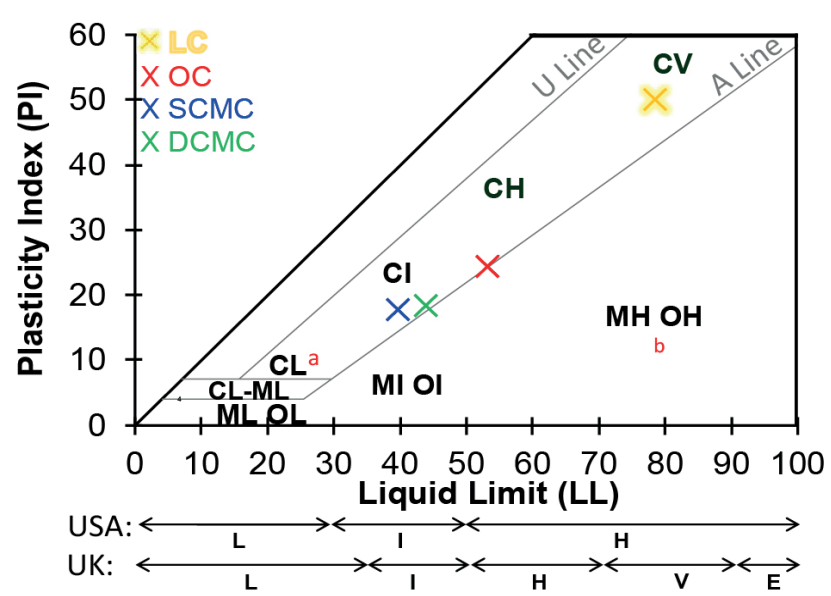

FIGURE 4: Plasticity chart for soil classification (<425- $\mu$ m fraction) of London Clay (LC), Oxford Clay (OC), shallow Coal Measures Clay (SCMC) and deep Coal Measures Clay (DCMC). Divisions of plasticity in: L: low, I: intermediate, $\mathrm{H}$ : high, $\mathrm{V}$ : very high and $\mathrm{E}$ : extremely high, according to USA and UK. O: significant organic material; C: clayey; M: silty and/or sandy (Unified Soil Classification System, USCS). ${ }^{a}$ dispersive clay fines, ${ }^{b}$ non dispersive clay fines. U-line: upper reference bound of $\mathrm{PI}$ for natural soils defined by two equations: $\mathrm{PI}=7$ if $\mathrm{LLs} \leq 16$, and $\mathrm{PI}=0.9$ (LL- 8) if LLs $>16$. A-line: reference boundary of PI between the clay soils (above line, mostly inorganic) and the silt soils (below it) defined also by two equations: $\mathrm{PI}=4$ if $\mathrm{LLs} \leq 25.5$, and $\mathrm{PI}=0.73$ (LL- 20) if $\mathrm{LLs}>25.5$ (Casagrande, 1947). an initial time equivalent to 8-15 yrs. Then, $\mathrm{K}$ decreased to comparable values at the start (Figure 6). Only on three separate occasions during leachate permeation through liners of $20 \%$ sand, $\mathrm{K}$ exceeded the maximum legal limit: in the beginning (between 0 and $3.1 \mathrm{yrs}$ ), in the middle (between 8.2 and $10 \mathrm{yrs}$ ) and towards the end (between 25.4$27.1 \mathrm{yrs}$ ). However, the average of $\mathrm{K}$ measurements taken in 9 different periods over a total modelled time equivalent to 32 yrs prototype of leachate through the liners of $20 \%$ sand was $0.8 \cdot 10^{-9} \mathrm{~m} / \mathrm{s}\left( \pm 0.6 \cdot 10^{-9}\right)$, and lower through the liners of $10 \%$ sand $\left(0.3 \cdot 10^{-9} \mathrm{~m} / \mathrm{s}\left( \pm 0.2 \cdot 10^{-9}\right)\right)$. When changing to rainwater though liners of $\approx 6 \%$ sand, there was also in the beginning a slight increase of $\mathrm{K}$ with time up to $0.5 \cdot 10^{-9} \mathrm{~m} / \mathrm{s}$, followed by a decrease with a stabilization around $0.2 \cdot 10^{-9} \mathrm{~m} / \mathrm{s}\left( \pm 0.1 \cdot 10^{-9}\right)$ from year 44 onwards (30 yrs of leachate permeation followed by 14 yrs of rainwater, Figure 6). The average of $\mathrm{K}$ for rainwater permeation taken over 16 periods of time within the total time modelled (53 yrs prototype) was $0.3 \cdot 10^{-9} \mathrm{~m} / \mathrm{s}\left( \pm 0.1 \cdot 10^{-9}\right)$ though the liners of $\approx 6 \%$ sand. The accumulated $\mathrm{K}$ calculated as a single measurement over the entire test time ( $\approx 19$ days each test) was very close to the average $\mathrm{K}$ calculated with all intermediate measurements taken every $\approx 2.3$ days over the 19-day tests (Table 3 ). This together with the small standard deviations of the $\mathrm{K}$ in liners with $10 \%$ or less sand, denotes that their $\mathrm{K}$ variation describe above was not very significant.

\section{DISCUSSION}

Based on the previous analysis, the feasibility of the four natural clayey substrata to attenuate landfill leachate is discussed below. Although its composition varies, landfill leachate always contains high concentrations of $\mathrm{Na}^{+}, \mathrm{K}^{+}$, bicarbonate and chloride, with significant $\mathrm{NH}_{4}^{+}$and organic compounds. The heavy metal content is generally relatively low, often of no major concern and limited to chromium, nickel and zinc (Aucott, 2006; Kjeldsen et al., 2002). As $\mathrm{NH}_{4}^{+}$ and $\mathrm{K}^{+}$are major elements in landfill leachate and virtually absent in these Ca-clay mineral liners, both can be used as tracers in leachate migration studies. The differences between the clayey substrata on porosity, density, sorption, surface, plasticity, permeability are due to their origin, particle size and mineralogy (Table 1 and from Figure 1 to 3 ). The presence of carbonaceous material is characteristic of clays formed in alluvial or shallow waters, as is the case with Coal Measures Clays (Bain, 1971). Smectite is often found interstratified with illite and in mixtures with chlori- 


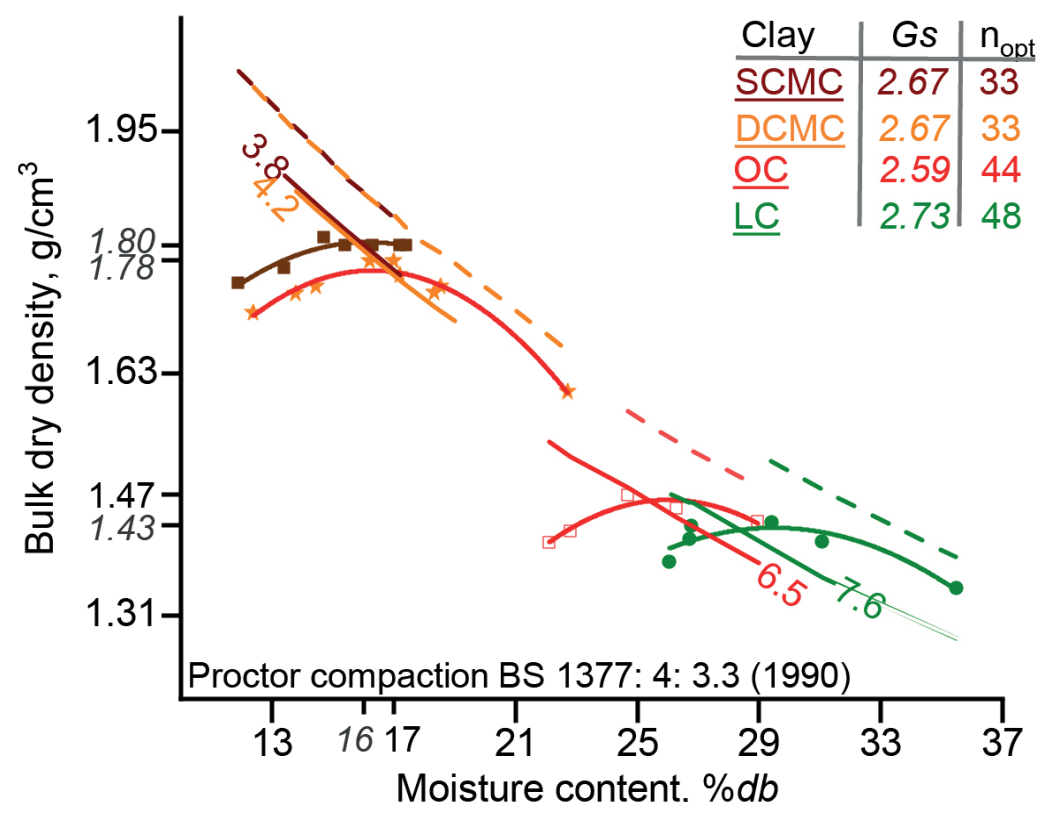

FIGURE 5: Air void lines (air vol\% of the total volume) and compaction curves under Proctor BS 1377:4:3.3 (1990) to estimate the (optimum) moisture contents at which the dry bulk densities are maximum. Dashed straights: zero air line or full (water) saturation lines ( $(=1)$. Solid straights: air void lines at the optimum. $\mathrm{n}_{\text {opt }}$ : porosities at the optimum (air plus water vol\% of the total volume). Gs: specific gravity (unitless). LC: London Clay, OC: Oxford Clay, SCMC: shallow Coal Measures Clay and DCMC: deep Coal Measures Clay.

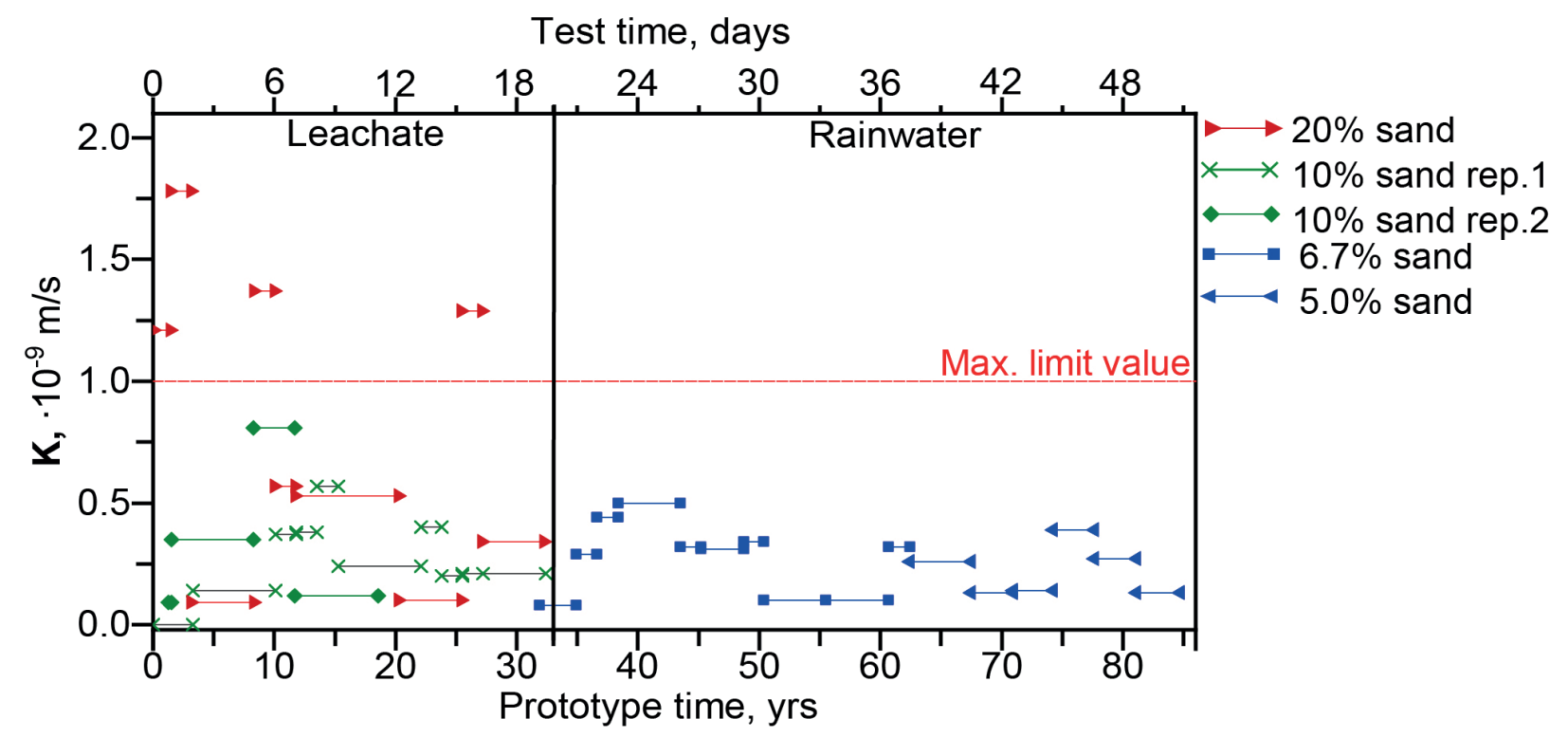

FIGURE 6: Hydraulic conductivities (K) of landfill leachate (from year 0 to 33 ) and rainwater (from year 33 to 82 ) through model liners ( $\approx 11$ ) of averaged compositions made of clays and mixtures of clays with sandy non-cohesive materials. The mixtures were used to decrease the plasticity of London and Oxford clays and therefore its associated risk of shrinkage.

te and sometimes kaolinite in deep sea marine sediments, as for the LC and OC. A high silica-to-aluminium ratio is characteristic of clays with smectite minerals (Weaver and Pollard, 1973), agreeing with that the LC had the highest values of this ratio and of smectite.

\subsection{Evaluation as attenuation liners}

In addition to the low permeability that they provide, compacted clays can attenuate leachate pollutants by sorption, dilution, redox transformations, biodegradation, precipitation and filtration (Allen, 2001; Griffin et al., 1976; Thornton et al., 1993). Attenuation here refers to a reduction of the mass of pollutants by naturally-occurring processes (Regadío et al., 2015). These attenuation processes occur simultaneously and can affect more than one pollutant in leachate. By sorption, pollutants are attached to mineral phases or particulate organic matter by a physical or chemical process, which encompasses ion exchange, adsorption, absorption and chemisorption. By redox transformations, organic and metal compounds are converted 
TABLE 3: Hydraulic conductivities in $\mathrm{m} / \mathrm{s}(\mathrm{K})$ as a single accumulated measurement within the entire test and as an average of the intermediate measurements taken every 2-3 days throughout the test.

\begin{tabular}{|c|c|c|c|c|}
\hline Average liner composition & Permeating test time & Permeating fluid & $\begin{array}{l}\text { One accumulated } \\
\text { measurement }\end{array}$ & $\begin{array}{c}\text { Average ( } \pm \text { standard } \\
\text { deviation) of intermediate } \\
\text { measurements }\end{array}$ \\
\hline Clays with $20 \%$ sand & From day 1 to 19 & Landfill leachate & $0.45 \cdot 10^{-9}$ & $0.81 \cdot 10^{-9}\left( \pm 0.61 \cdot 10^{-9}\right)$ \\
\hline Clays with $10 \%$ sand (1) & From day 1 to 19 & Landfill leachate & $0.21 \cdot 10^{-9}$ & $0.25 \cdot 10^{-9}\left( \pm 0.17 \cdot 10^{-9}\right)$ \\
\hline Clays with $10 \%$ sand (2) & From day 1 to 19 & Landfill leachate & $0.29 \cdot 10^{-9}$ & $0.27 \cdot 10^{-9}\left( \pm 0.33 \cdot 10^{-9}\right)$ \\
\hline Clays with $6.7 \%$ sand & From day 19 to 36 & Rainwater & $0.25 \cdot 10^{-9}$ & $0.28 \cdot 10^{-9}\left( \pm 0.14 \cdot 10^{-9}\right)$ \\
\hline Clays with $5.0 \%$ sand & From day 36 to 48 & Rainwater & $0.22 \cdot 10^{-9}$ & $0.22 \cdot 10^{-9}\left( \pm 0.11 \cdot 10^{-9}\right)$ \\
\hline
\end{tabular}

(1) and (2) are replicates.

into less toxic or immobile forms by electron transfer reactions. By biodegradation, organic pollutants are chemically decomposed by microorganisms. By precipitation, metallic pollutants become less bioavailable or mobile. By filtration, larger pollutants such as metal-organo complexes in the leachate remain physically trapped within the liner fabric.

The surface of soil particles is critical for the chemical reactions, sorption, colloid filtration, and transport of contaminants. All clayey materials and especially the OC contained particulate organic matter (Table 1, Figure 3 right, Figure 4) which has a large surface area and CEC. Particulate organic matter is important for the attenuation of contaminant molecules by sorbing them to its surface or fostering microbial communities that would breakdown the contaminants to less toxic or nontoxic compounds (see biodegradation below). The CEC in particulate organic matter and also in clay minerals is especially important for sorption. In this case cations in the pore water are sorbed by clays to neutralize their negative charge created by unbalanced substitutions of their structural cations. Sorbed native cations can be replaced by cationic pollutants in the leachate. Illites (present in the four clays here) have high affinity for selective sorption of $\mathrm{NH}_{4}^{+}$and $\mathrm{K}^{+}$due to their size compatibility with the interlayer (exchange) sites in this clay lattice (Griffin et al., 1976). Smectites (in the LC) also fix these cations but this destabilizes smectitic minerals, resulting in illitization, i.e., partial collapse of smectites with their subsequent conversion into illite. In the case of larger cations, organic cations or organometallic complexes in leachate, smectites sorbed these species preferentially relative to smaller, inorganic or uncomplexed metals (Koutsopoulou and Kornaros, 2010). This is because for the same valence these weakly hydrated cations are the easiest to sorb in the exchange sites than stronger hydrated small cations (Teppen and Miller, 2006), and only smectites have an exchanger interlayer space large enough to accommodate them. Smectite, along with vermiculite (interlayer $\mathrm{Mg}$ ), has a high $\mathrm{CEC}$, while illite has mid-range values and kaolinite very low values. Thus, the capacity to reduce the concentration of cationic pollutants in leachate by cation exchange reactions follows the order $\mathrm{LC}>\mathrm{OC}>$ Coal Measures Clays. CEC generally increases with $\mathrm{pH}$ due to the development of greater negative charge (average $\mathrm{pH}$ in leachate is 7-8).

Anion sorption (bicarbonate, chloride, sulphate from leachate) is less efficient and very similar for the different clay minerals (kaolinite, smectite). It occurs at $\mathrm{OH}^{-}$ions exposed on the mineral edges and is enhanced by positively charged iron-oxide colloids (present in LC and Coal Measures Clays) associated with clays (Raymahashay, 1987). Bicarbonate is the major inorganic anionic compound in leachate and largely determines the acid-base neutralisation potential of the system. This is good for Coal Measures Clays which have no $\mathrm{pH}$ buffering capacity to attenuate acidic episodes caused for example by oxidation of sulphides (pyrite) by infiltrating rainwater (Thornton et al., 2001). This oxygenated water can re-oxidized sulphide phases, resulting in the release of previously attenuated metals that precipitated earlier in such immobile phases (Regadío et al., 2013). Bicarbonates in the leachate itself would provide acid neutralization capacity to Coal Measure Clays which lack calcite. The acidity in Coal Measures Clays most likely arises from oxidation of pyrite in the upper, weathered zone, which produces a low $\mathrm{pH}$, gypsum and amorphous iron oxides as by-products. Chloride is not significantly attenuated and mainly diffuses through the clay liner, together with $\mathrm{Na}^{+}$and the cations displaced from the exchange sites of clays (usually $\mathrm{Ca}^{2+}$ and $\mathrm{Mg}^{2+}$ substituted by $\mathrm{NH}_{4}^{+}, \mathrm{K}^{+}$) (Regadío et al., 2012; Zhan et al., 2014). These elements are diluted by the receiving groundwater and are generally not a problem due to its low toxicity even at relatively high concentrations. Sulphate in leachate is attenuated by anaerobic microbial reduction, a common redox process in landfills (Batchelder et al., 1998). All the studied clayey substrata contain redox-sensitive species, the most important being pyrite in the $O C$ and SCMC, and iron oxides in the LC, SCMC and DCMC. As a result, these clays support the metals to precipitate as sulphides in the liner and the sulphate is in low concentration in leachate.

Biodegradation is also accompanied by changes in redox potential in the landfill, which results in transformation of organic and inorganic species by reactions under aerobic and a range of anaerobic conditions. Depending on the specific redox conditions in the landfill and liner (aerobic, nitrate-reducing, iron-reducing, sulphate-reducing, etc.), one or other organic compounds can be biodegraded (Bright et al., 2000). The concentration of the oxidising agents and their reduced species in the leachate indicates the redox conditions (Taylor and Allen, 2006). Differences in clay minerals have a minor effect on the biodegradation 
of organic pollutants than on the sorption of inorganic pollutants. This is because organic pollutants are attenuated mainly by anaerobic biodegradation (Thornton et al., 2000; Bright et al., 2000; Adar and Bilgili, 2015), rather than by sorption to clay minerals, in which case only smectite, chlorite and vermiculite would show significant organic sorption (Koutsopoulou and Kornaros, 2010). The decomposition of organic compounds down to water, methane and carbon dioxide, depends on the establishment of an appropriate microbial population. The native particulate organic matter of clay materials is essential to support in situ biological activity in liners, with the highest organic matter content found in the OC (followed by SCMC), sampled from a fossiliferous location (Martill et al., 1994). Anaerobic degradation in the liner is also sustained by the microbial inoculum in the leachate itself.

The attenuation of heavy metals in leachate is associated with particulate organic matter and mineral phases, including clay minerals in liners, and occurs by a combination of sorption, redox transformation and precipitation processes (Fannin, 2006). These processes are supported by specific mineral phases such as sulphate-bearing species (pyrite, gypsum), iron and manganese oxides and oxyhydroxides, and clays (mainly smectite and illite) (Fisher and Hudson, 1987). The studied materials all contain a high content of clay minerals which assists retention of heavy metals. The OC and SCMC contain pyrite, and the LC, SCMC and DCMC contain iron/metal oxides. The high native particulate organic matter content of the $\mathrm{OC}$ favours sorption of metals, whereas the dissolved organic compounds in leachate favour the formation of soluble metalorgano complexes. Despite the fact that metal-organo complexes are dissolved in leachate and therefore mobile, they can be attenuated by filtration due to their larger size (Christensen et al., 1996; Gregson et al., 2008). However, a proportion of metals complexed with dissolved organic matter or associated with colloids in leachate may not be attenuated (Thornton et al., 2001).

\subsection{Evaluation as containment liners}

None of the clays here were identified susceptible to dispersion in the field. Dispersive clays resemble normal clays but can be highly erosive and susceptible to severe damage or failure. Soils of high plasticity silt $(\mathrm{MH}$ in the USCS classification, Figure 4) and smetite-rich materials (LC) rarely contain dispersive clays. In the case of the LC, smectites are responsible for the adhesion forces between particles, which helps to prevent dispersion and thus soil erosion. The locations of the clays on or above the "A-line" on the plasticity chart (Figure 4), denotes a relatively low silt content so they are easy to compact well, resulting in low erodibility. The high OMCs of the OC and LC (25-29\% with maximum dry bulk densities of $1.43-1.47 \mathrm{~g} /$ $\mathrm{cm}^{3}$ ), indicate the abundance of clay-sized particles (heavy clays) as silt-rich soils have medium values and sandy materials have very low values. Coal Measures Clays had $16-17 \%$ of OMC with maximum dry bulk densities of 1.78 $1.80 \mathrm{~g} / \mathrm{cm}^{3}$, being more characteristics of sandy-clay materials. In the case of shrinkage potential, only LC presented high risk because of the smectites. Concordantly, the
LC was classified as high shrinkage (average shrink limits of $16.8 \pm 4.8 \%$ ) compared to the $\mathrm{OC}$ as medium shrinkage (14.5 $\pm 2.0 \%)$ in Hobbs et al. (2019). In addition, smectites can also sorb larger quantities of water that decrease the soil strength, causing destructive landslides and slope failure (Borchardt, 1977; Wagner, 2013; Yalcin, 2007). To ensure landfill liner stability, clays should have PIs of 15$30 \%$ (25\% is good) and clays with $\mathrm{PI}>40 \%$ should not be used on their own.

The LC and OC are plastic clays and thus contain little sand and much clay, with a particular abundance of swelling minerals (illite and smectite). These are expandable sheet silicates with desirable properties such as erosion resistance, low permeability and excellent ability to attenuate pollutants, due to high surface area and CEC (e.g., the LC). Thus, they have been used globally to improve compacted soil liners (Ruiz et al., 2012) and to achieve permeabilities in geosynthetic clay liners in the low range of $0.10 \cdot 10^{-9}-0.01 \cdot 10^{-9} \mathrm{~m} / \mathrm{s}$ (Egloffstein, 2001). A key limitation is that smectites are plastic minerals very sensitive to the cation occupying the hydrated interlayer, which results in a high potential for swelling or shrinkage in water or leachate, respectively. This property can induce instability and cracks in compacted clays and increase leakage through liners (Borchardt, 1977; Wagner, 2013; Yalcin, 2007). This risk can be reduced by compaction and by addition of sand (Tanit and Arrykul, 2005; Varghese and Anjana, 2015). No consensus exists though on whether applying a water content lower (Widomski et al., 2018) or higher (Benson et al., 1999) than the optimum, will limit the shrink potential and thus desiccation cracking, ensuring $\mathrm{K}$ values $\leq 1 \cdot 10^{-9} \mathrm{~m} / \mathrm{s}$. A further drawback of smectites is that their alteration to newly formed illite or even kaolinite results in much less chemo-mechanical stable materials than kaolinite-rich and illite-rich samples that are not originally derived from smectite (Zhao et al., 2007). This illitization at the expense of the smectite content can occur after ammonium and potassium sorption from the landfill leachate (Regadío et al., $2015)$, reducing the CEC of the clay by $\leq 10 \%$.

The Coal Measures Clays were easily compacted until negligible air was present in their voids (4\%), which is convenient to achieve a low permeability in the liner. The OC and LC can achieve the lowest K (Maritsa et al., 2016) due to their high plasticity, but also have a higher shrinkage risk, with consequent risk of increased $\mathrm{K}$ due to desiccation cracks. This is especially critical in the LC as its $\mathrm{PI}$ is $>30 \%$ : the low $\mathrm{K}$ of compacted clay liners with such high plasticity could increase above the design specification after repeated cycles of shrinkage-by-drying and swelling-by-wetting, and never recover its initial value even after rewetting (Widomski et al., 2018). Conversely, low plasticity clays have a $K$ that remains nearly constant and within the design specification, even after several drying/wetting cycles. Another advantage is that non-plastic clays exhibit predominant vertical instead of horizontal deformation, the latter being predominant in plastic clays. Vertical deformation presents a lower risk of desiccation cracking in a compacted clay liner. Thus, for the centrifuge permeability tests the sandy materials were added to both clays to decrease their plasticity (Mansouri et al., 2013; Tanit and Arrykul, 2005; Varghese and Anjana, 2015). 
Adding non-cohesive materials decreases the $\mathrm{LL}$ and swell index, but should be done with caution to avoid an excessive increase in $\mathrm{K}$ (Lee et al., 2005). The $\mathrm{K}$ varies depending on the solid properties (surface area, particle sizes, porosity, tortuosity...), and many factors such as:

- Lab or field measurements (Allen, 2000; Benson et al., 1999; Shackelford and Javed, 1991);

Compaction (Herrmann et al., 2009);

(liquid) saturation ratio (Benson et al., 1999; Widomski et al., 2018);

- Other minor construction variables (Benson et al., 1999);

- Permeating liquid (di Emidio et al., 2017; Francisca and Glatstein, 2010; Jo et al., 2001; Lee et al., 2005; Singh and Prasad, 2007; Stepniewski et al., 2011; Uma Shankar and Muthukumar, 2017);

- Methodology (Sandoval et al., 2017);

- Passing of time and wet-dry seasonal variations (di Emidio et al., 2017; Egloffstein, 2001; Mitchell and Jaber, 1990; Stepniewski et al., 2011; Widomski et al., 2016).

The low K measurements $\left(0.2-0.8 \cdot 10^{-9} \mathrm{~m} / \mathrm{s}\right)$ showed that these clayey substrates are chemically compatible with landfill leachates and promising candidates for use in the design of landfill bottom liners to minimize leachate migration as dual impermeability-attenuation barriers. The $K$ values in the clay liners with $\leq 10 \%$ sandy materials under long-term leachate and rainwater permeation were below the most common maximum regulatory criterion $\left(1 \cdot 10^{-9}\right.$ $\mathrm{m} / \mathrm{s}$ ) over a time equivalent to $85 \mathrm{yrs}$. These experimental results are in line with the graphical and multivariate regression of Benson et al. (1994), which estimates K values of $<1 \cdot 10^{-9} \mathrm{~m} / \mathrm{s}$ for materials with at least $20 \% \mathrm{LL}, 7 \% \mathrm{PI}$, $30 \%$ fines and $15 \%$ clays. No significant differences were found between the $K$ values measured between different periods of time. The little variation is most likely due to the not complete (but almost) saturation of the compacted liners at the beginning (Darcy, 1856). This results in measurements of unsaturated $\mathrm{K}$ whose values are typically lower than those of saturated $K$ as the water would be strongly attracted by the tension of the dry soil. The possible loss of the hydraulic connection when the pore water at the bottom of the model liner is transferred to the collector during spinning would also promote unsaturated conditions with lower K. Additionally, there are other processes that can also be affecting $\mathrm{K}$. The leachate, with a high concentration and valence of ions, would decrease the net particle charge (Chorom and Rengasamy, 1995) and thickness of the Diffuse Double Layer (di Emidio et al., 2017; Schmitz, 2006; Stepniewski et al., 2011) in an initial stage. The former is due to the decrease in the dispersion of clays and the latter is relevant for the high porosity of freshly compacted soils. For Ca-clay minerals like here, the maximum dispersion occurs at pH 6.5-7.7 (Chorom and Rengasamy, 1995), which is the $\mathrm{pH}$ for most leachates. As a result, the transport of charged species in clays with high plasticity is enhanced, resulting in an increase of $\mathrm{K}$ in the first years. This supports earlier observations of an increase of $K$ with the leachate concentration (Mitchell and Soga, 2005). In a later stage the precipitation of mineral phases and the growth of microbial activity may contribute to pore clogging (Francisca and Glatstein, 2010; Stepniewski et al., 2011) and therefore the decrease of $\mathrm{K}$ after its maximum during the previous stage (Figure 6). Calcite is likely to precipitate within the liner due to the basic $\mathrm{pH}$, the high leachate bicarbonate concentration and additional dissolved calcium released over time by cation exchange reactions with the liner (de Soto et al., 2012; Thornton et al., 2001).

\section{CONCLUSIONS}

The performance of four natural clayey substrata as potential landfill liners was assessed by measuring their physico-chemical properties and stability and alterability upon contact with leachate, followed by rainwater. The attenuation of pollutants in leachate depends on the pollutant species and liner mineralogy. Potassium, ammonium, (dissolved) organic compounds and heavy metals (chromium, nickel and zinc) are the most representative leachate pollutants, according to their concentration, toxicity or persistence. All studied clayey materials are useful for the attenuation of leachate pollutants in sustainable waste landfills. These pollutants are mainly attenuated in the clayey materials by anaerobic biodegradation and sorption mechanisms, especially cation exchange. Chloride and sodium in leachate and native cations released from exchange sites on the clay liner after sorption of pollutants can be diluted by groundwater. However, different management options should be applied depending on the clayey material. The LC is the best material based on the sorption capacity and erosion resistance. However, the LC has a large plasticity (high susceptibility to excessive shrinkage) and easily alterable smectite clay minerals that partially collapse to illitic structures. Illitization has less impact on the CEC of the liner than on its chemo-mechanical stability and could be countered by compacting and mixing LC with sands. The $\mathrm{OC}$ is also plastic but to a lesser extent, with an acceptable PI. This substratum has a significant sorption capacity and is the best material for buffering acid leachates (due to native calcite) and supporting biodegradation of organic compounds. On the negative side, Coal Measures Clays have the lowest sorption capacity and zero neutralization power. However, they have the lowest plasticity and the most resistant clay minerals (kaolinite accompanied by illite) to alteration by exposure to leachate. In addition, both Coal Measures Clays are easily compacted until negligible air voids, which favours the achievement of a low $\mathrm{K}$. The SCMC contained sulphate-bearing species (resulting from oxidation of pyrite) that enhance the retention by precipitation of heavy metals through bacterial sulphate reduction in the liner. The DCMC had very low mineral phases or inorganic salts that are readily dissolved in water. This is advantageous as it results in less mobilization of leachable salts from the liner itself. The LC and Coal Measures Clays have associated iron/metal oxides and oxyhydroxides that can enhance anion exchange and the removal of metals by sorption. Redox-sensitive species such as pyrite (OC and SCMC) and iron oxides (LC and Coal Measures Clays) can 
enhance the removal of metals by bacterially-mediated redox transformation and precipitation processes. The presence of pyrite and iron oxides also determines to a large extent the acid-base neutralisation potential, together with native carbonates in $\mathrm{OC}$ and bicarbonates in the leachate. After permeation with landfill leachate and rainwater during several weeks (equivalent to years under field conditions), the model liners achieved long-term sustainable low $\mathrm{K}$, that rarely surpassed the maximum value specified for liner design.

\section{ACKNOWLEDGEMENTS}

This project has received funding from the European Union's Horizon 2020 research and innovation programme under grant agreement No 743880. This work reflects only the author's view, exempting the community from any liability. The authors thank TerraConsult Ltd and Soil Hill Quarries Ltd for providing the clay materials; technicians of the Dept of Civil and Structural Engineering and Dept of Chemical and Biological Engineering for general support (The University of Sheffield), J Cuevas and A Ortega for XRD analyses (Autonomous University of Madrid); the German-Austrian-Swiss Clay Group (DTTG), Craig Fannin (TerraConsult Ldt) and the Solid Waste Institute for Sustainability (SWIS) for insightful discussions.

\section{REFERENCES}

Adar, E. and Bilgili, M. S. (2015). The Performance of Four Different Mineral Liners on the Transportation of Chlorinated Phenolic Compounds to Groundwater in Landfills. Sci. World. J., 2015, 171284. doi.org/10.1155/2015/171284.

Allen, A. (2000). Attenuation Landfills - the Future in Landfilling. Chap. 17. 18 pp. ros.edu.pl/images/roczniki/archive/pp_2000_017.pdf.

Allen, A. (2001). Containment landfills: the myth of sustainability. Eng. Geol., 60, 3-19. doi.org/10.1016/S0013-7952(00)00084-3.

ASTM D 4318 Standard Test Methods for Plastic Limit of Soils, 2015 (American Standard).

Aucott, M. (February 2006). The fate of heavy metals in landfills: A Review. Report based on the Project of "Industrial Ecology, Pollution Prevention and the NY-NJ Harbor" Funded by New York Academy of Sciences.

Bain, J. A. (1971). "A plasticity chart as an aid to the identification and assessment of industrial clays." Clay Miner, 9(1): 1-17.

Batchelder, M., Mather, J.D., Joseph, J.B. (1998). The Stability of the Oxford Clay as a Mineral Liner for Landfill. Water Environment J. - ClWEM, 12 (2), 92-97. doi.org/10.1111/j.1747-6593.1998.tb00155.x.

Beaven, R., Potter, H., Powrie, W., Simoes, A., Smallman, D., Stringfellow. A (2009). Attenuation of organic contaminants in leachate by mineral landfill liners. Environment Agency, Integrated Catchment Science programme. Science report: SC020039/SR5 Project record. 249 pp. ISBN: 978-1-84911-067-9.

Benson, C., Zhai, H., Wang, X. (1994). Estimating Hydraulic Conductivity of Compacted Clay Liners. J. Geotech. Eng., 120(2). doi. org/10.1061/(ASCE)0733-9410(1994)120:2(366).

Benson, C. H., Daniel, D. E., Boutwell, G. P. (1999). Field performance of compacted clay liners. J Geotech Geoenviron Eng, 125(5), 390403. doi.org/10.1061/(asce)1090-0241(1999)125:5(390).

Bertier, P., Schweinar, K., Stanjek, H., Ghanizadeh, A., Clarkson, C. R., Busch, A., Kampman, N., Prinz, D., Amann-Hildenbrand, A., Krooss, B. M., Pipich, V. (2016). On the Use and Abuse of N2 Physisorption for the Characterization of the Pore Structure of Shales. In The Clay Minerals Society Workshop Lectures Series, Vol. 21, Chapter 12, 151-161. doi.org/10.1346/CMS-WLS-21-12.

Borchardt, G. (1977). Montmorillonite and other smectite minerals. Minerals in soil environments (pp. 293-330). Madison: Soil Science Society of America.

BS 1377: Part 2 Classification tests: 4.3 Point Liquid Limit, 1990 (British Standard).
BS 1377: Part 2 Classification tests: 5.3 Point Plastic Limit, 1990 (British Standard).

BS 1377: Part 2 Classification tests: 8.3 Particle Density (Small Pyknometer), 1990 (British Standard).

BS 1377: Part 4 Compaction-related tests: 3.3 Method using 2.5 kg rammer for soils with particles up to medium-gravel size, 1990 (British Standard Proctor).

Bright, M. I., Thornton, S. F., Lerner, D. N., Tellam, J. H. (2000). Attenuation of landfill leachate by clay liner materials in laboratory columns: 1. Experimental procedures and behaviour of organic contaminants. Waste Manag Res, 18(3), 198-214. doi. org/10.1177/0734242X0001800302.

Casagrande, A. (1947). Classification and identification of soils. Proceedings of the American Society of Civil Engineers, 73(6): 783810.

Christensen, J. B., Jensen, D. L., Christensen, T. H. (1996). Effect of dissolved organic carbon on the mobility of cadmium, nickel and zinc in leachate polluted groundwater. Water Res., 30(12), 3037-3049. doi.org/10.1016/S0043-1354(96)00091-7.

Chorom, M. and Rengasamy, P. (2005). Dispersion and zeta potential of pure clays as related to net particle charge under varying $\mathrm{pH}$, electrolyte concentration and cation type. Eur J Soil Sci. 46. 657 - 665. doi.org/10.1111/j.1365-2389.1995.tb01362.x.

Darcy, H. (1856) In: Dalmont, V., Ed., Les Fontaines Publiques de la Ville de Dijon: Exposition et Application des Principes a Suivre et des Formulesa Employer dans les Questions de Distribution d'Eau. Paris, $647 \mathrm{p}$.

Edmeades, D. C. and Clinton, O. E. (1981). A simple rapid method for the measurement of exchangeable cations and effective cation exchange capacity. Commun. Soil Sci. Plant, 12(7), 683-695. doi. org/10.1080/00103628109367184.

Egloffstein, T.A. (2001). Natural bentonites-influence of the ion exchange capacity and partial desiccation on permeability and selfhealing capacity of bentonites used in GCLs. Geotext. Geomembranes, 19, 427- 444 .

di Emidio, G., Verastegui-Flores, R. D., Mazzieri, F., Dominijanni, A. (2017). Modified clays for barriers: a review. Innov. Infrastruct. Solut., 2(1). doi.org/10.1007/s41062-017-0073-8.

Fannin, C. A. (2006). An evaluation of the chemical attenuation capacity of UK mineral liner and geological barrier materials for landfill leachate components. Q. J. Eng. Geol. Hydroge., 39(3), 267-281. doi.org/10.1144/1470-9236/04-073.

Fisher, I. St. J. and Hudson, J. D. (1987). Pyrite formation in Jurassic shales of contrasting biofacies. Geol. Soc. London, Special Publications, 26(1), 69-78. doi.org/10.1144/GSL.SP.1987.026.01.04.

Francisca, F. M. and Glatstein, D. A. (2010). Long term hydraulic conductivity of compacted soils permeated with landfill leachate. Appl. Clay Sci, 49(3), 187-193. doi.org/10.1016/j.clay.2010.05.003.

Freeman, I. L. (1964). Mineralogy of ten british brick clays. Clay Miner. B. $5,474-486$.

Gregson, S.K., Roberts, R.D., Roberts, J.M. (2008). The fate of heavy metals in co-disposed refuse. Environ. Technol. Lett., 9(9), 983990. doi.org/10.1080/09593338809384660.

Griffin, R. A., Shimp, N. F., Steele, J. D., Ruch, R. R., White, W. A., Hughes, G. M. (1976). Attenuation of pollutants in municipal landfill leachate by passage through clay. Environ. Sci. Technol., 10(13), 12621268. doi.org/10.1021/es60123a006.

Head, K. H. (1994). Manual of Soil Laboratory Testing Volume 2: Permeability, shear strength and compressibility tests (Second Edition ed.): CRC Press Taylor \& Francis Group.

Head, K. H. (2006). Manual of Soil Laboratory Testing Volume 1: Soil Classification and Compaction Tests (Third Edition ed.): CRC Press Taylor \& Francis Group.

Herrmann, I., Svensson, M., Ecke, H., Kumpiene, J., Maurice, C., Andreas, L., Lagerkvist, A. (2009). Hydraulic conductivity of fly ashsewage sludge mixes for use in landfill cover liners. Water Res, 43(14), 3541-3547. doi.org/10.1016/j.watres.2009.04.052.

Hobbs, P. R. N., Jones, L. D., Kirkham, M. P., Gunn, D. A., Entwisle, D. C. (2019). Shrinkage limit test results and interpretation for clay soils. Q J Eng Geol Hydroge, 52(2), 220-229. doi.org/10.1144/ qjegh2018-100.

Holden, A. A., Mayer, K. U., Ulrich, A. C. (2012). Evaluating methods for quantifying cation exchange in mildly calcareous sediments in Northern Alberta. Appl. Geochem., 27(12), 2511-2523. doi. org/10.1016/j.apgeochem.2012.08.026. 
Hudson, J. D. and Martill, D. M. (1994). The Peterborough Member (Callovian, Middle Jurassic) of the Oxford Clay Formation at Peterborough, UK. J. Geol. Soc. London, 151(1), 113. doi.org/10.1144/ gsjgs.151.1.0113.

Jo H, Katsumi T, Benson CH, Edil TB (2001) Hydraulic conductivity and swelling of non-prehydrated gcls premeated with single species salt solutions. J Geotech Geoenviron Eng ASCE 127(7):557-567 doi.org/10.1061/(ASCE)1090-0241(2001)127:7(557).

Kaza S., Yao Lisa C., Bhada-Tata P., Van Woerden F. (2018). What a Waste 2.0: A Global Snapshot of Solid Waste Management to 2050. Urban Development. Washington, DC. (CWorld Bank. https:// openknowledge.worldbank.org/handle/10986/30317 License: CC BY 3.0 IGO.

Kavazanjian, E., Dixon, N., Katsumi, T., Kortegast, A., Legg, P., Zanzinger, H. (2006). Geosynthetic barriers for environmental protection at landfills. Paper presented at the 8th International Conference on Geosynthetics, 8 ICG, Yokohama. Japan.

Kemp, S.J. and Wagner, D. (2006). The mineralogy, geochemistry and surface area of mudrocks from the London Clay Formation of southern England (IR/06/060) (pp. 81). Nottingham, UK British Geological Survey.

Kjeldsen, P., Barlaz, M. A., Rooker, A. P., Baun, A., Ledin, A., Christensen T. H. (2002). Present and long-term composition of MSW landfil leachate: A review. Crit. Rev. Env. Sci. Tec., 32(4), 297-336. doi. org/10.1080/10643380290813462.

Kong, D. J., Wu, H. N., Chai, J. C., Arulrajah, A. (2017). State-of-theArt Review of Geosynthetic Clay Liners. Sustainability, 9(11). doi. org/10.3390/su9112110.

Koutsopoulou, E., Papoulis, D., Tsolis-Katagas, P., Kornaros, M. (2010). Clay minerals used in sanitary landfills for the retention of organic and inorganic pollutants. Appl. Clay Sci., 49(4), 372-382. doi. org/10.1016/j.clay.2010.05.004

Lee JM, Shackelford CD, Benson CH, Jo HY, Edil TB (2005) Correlating index properties and hydraulic conductivity of geosynthetic clay liners. J Geotech Geoenviron Eng 131(11):1319-1329. doi. org/10.1061/(ASCE)1090-0241(2005)131:11(1319).

Louati, F., Trabelsi, H., Jamei, M., Taibi, S. (2018). Impact of wetting-drying cycles and cracks on the permeability of compacted clayey soil. Eur. J. Environ. Civ. En., 1-26. doi.org/10.1080/19648189.20 18.1541144 .

Mansouri, H., Ajalloeian, R., Sadeghpour, A. H. (2013). The investigation of salinity effects on behavioral parameters of fine-grained soils. Paper presented at the 7th International Conference on Case Histories in Geotechnical Engineering.

Maritsa, L., Tsakiridis, P. E., Katsiotis, N. S., Tsiavos, H., Velissariou, D. Xenidis, A., Beazi-Katsioti, M. (2016). Utilization of spilitic mining wastes in the construction of landfill bottom liners. J Environ Chem Eng, 4(2), 1818-1825. doi.org/10.1016/j.jece.2016.03.011.

Martill, D. M., Taylor, M. A, Duff, K. L, Riding, J.B, Bown, P. R. (1994). The trophic structure of the biota of the Peterborough Member Oxford Clay Formation (Jurassic), UK. J. Geol. Soc. London, 151, 173-194. doi.org/10.1144/gsjgs.151.1.0173.

McEvoy, F. M., Minchin, D., Harrison, D. J., G., Cameron D., Steadman, E. J., Hobbs, S. F., Spencer, N. A., Evans, D. J., Lott, G. K., Highley, D. E. (2016). Mineral Resource information in Support of National Regional and Local Planning: West Yorkshire (comprising Metropolitan Boroughs of Bradford, Calderdale, Kirklees and Wakefield and City of Leeds). Commissioned Report, CR/04/172N (pp. 209): British Geological Survey.

Mitchell, J.K. and Jaber, M. (1990). Factors controlling the long-term properties of clay liners. Waste containment systems: construction, regulation and performance. ASCE. Geotechnical Special Publication 26, 84-105.

Mitchell, J.K. and Soga, K. (2005). Fundamentals of Soil Behavior, 3rd Edition. John Wiley \& Sons, Hoboken. ISBN: 978-0-471-46302-3.

Moore, D. M. and Reynolds, R. C., Jr. (1997). X-Ray Diffraction and the Identification and Analysis of Clay Minerals. (2nd ed. Xviii ed. Vol. 135). Oxford, New York: Oxford University Press.

$\mathrm{Ng}, \mathrm{C} . \mathrm{W}$. W. (2014). The state-of-the-art centrifuge modelling of geotechnical problems at HKUST. J Zhejiang Univ Sci A, 15(1), 1-21. doi.org/10.1631/jzus.A1300217.

Raymahashay, B.C. (1987). A comparative study of clay minerals for pollution control. J. Geol. Soc. India, 30(5), 408-413.

Regadío, M., Cargill, A., Black, J. A., Thornton, S. F. (2020). High Attenuation Recycled Materials as landfill liners (the HARM project) - A new concept for improved landfill liner design. EarthArXiv, 15 pp. doi.org/10.31223/osf.io/b49hd.
Regadío, M., Ruiz, A. I., de Soto, I. S., Rodriguez-Rastrero, M., Sánchez, N., Gismera, M. J., Sevilla, M. T., da Silva, P., Rodríguez-Procopio, J., Cuevas, J. (2012). Pollution profiles and physicochemical parameters in old uncontrolled landfills. Waste Manage., 32(3), 482-497. doi.org/10.1016/j.wasman.2011.11.008

Regadío, M., Ruiz, A. I., Rodríguez-Rastrero, M., Cuevas, J. (2015). Containment and attenuating layers: An affordable strategy that preserves soil and water from landfill pollution. Waste Manage., 46, 408-419. doi.org/10.1016/j.wasman.2015.08.014.

Regadío, M., de Soto, I. S., Rodríguez-Rastrero, M., Ruiz, A. I., Gismera, M. J., Cuevas, J. (2013). Processes and impacts of acid discharges on a natural substratum under a landfill. Sci. Total Environ, 463 , 1049-1059. doi.org/10.1016/j.scitotenv.2013.06.047

Rowe, R. K. and Sangam, H. P. (2002). Durability of HDPE geomembranes. Geotext. Geomembranes, 20(2), 77-95. doi.org/10.1016/ s0266-1144(02)00005-5

Rowe, R. K., Sangam, H. P., Lake, C. B. (2003). Evaluation of an HDPE geomembrane after 14 years as a leachate lagoon liner. Can. Geotech. J. NRC Canada, 40, 536-550. doi.org/10.1139/T03-019.

Ruiz, A. I., Fernández, R., Jiménez, N. S., Rastrero, M. R., Regadío, M., de Soto, I. S., Cuevas, J. (2012). Improvement of attenuation functions of a clayey sandstone for landfill leachate containment by bentonite addition. Sci. Total Environ, 419, 81-89. doi.org/10.1016/j.scitotenv.2011.11.054.

Sandoval, G. F. B., Galobardes, I., Teixeira, R. S., Toralles, B. M. (2017) Comparison between the falling head and the constant head permeability tests to assess the permeability coefficient of sustainable Pervious Concretes. Case Studies in Construction Materials, 7, 317-328. doi.org/10.1016/j.cscm.2017.09.001

Schmitz, R.M. (2006). Can the diffuse double layer theory describe changes in hydraulic conductivity of compacted clay? Geotech. Geol. Eng. 24. 1835-1844.

Scotney, P. M., Joseph, J. B., Marshall, J. E. A., Lowe, M. J., Croudace, I. W., Milton, J. A. (2012). Geochemical and mineralogical properties of the Lower Callovian (Jurassic) Kellaways Sand, variations in trace element concentrations and implications for hydrogeological risk assessment. Q. J. Eng. Geol. Hydroge., 45(1), 45-60. doi. org/10.1144/1470-9236/11-005

Seed, H.B., Woodward, R.J., Lundgren, R. (1962). Prediction of swelling potential for compacted clays. Soil Mech. Found. Div.Am. Soc. Civil Eng., 88, 53-87.

Shackelford, C. and Javed, F. (1991). Large-Scale Laboratory Permeability Testing of a Compacted Clay Soil. Geotech Test J, 14, no. 2 171-179. doi.org/10.1520/GTJ10559J.

Singh, S. and Prasad, A. (2007). Effects of Chemicals on Compacted Clay Liner. EJGE, 12, Bund. D, 1-15.

de Soto, I. S., Ruiz, A. I., Ayora, C., Garcia, R., Regadío, M., Cuevas, J. (2012). Diffusion of landfill leachate through compacted natural clays containing small amounts of carbonates and sulfates. Appl. Geochem., 27(6), 1202-1213. doi.org/10.1016/j.apgeochem.2012.02.032

Stepniewski, W., Widomski, M. K., Horn, R. (2011). Hydraulic Conductivity and Landfill Construction. In D. O. (Ed.), Developments in Hydraulic Conductivity Research (pp. 249-227). Rijeka,Croatia: INTECH.

Stanjek, H. and Künkel, D. (2016). CEC determination with Cu-triethylenetetramine: recommendations for improving reproducibility and accuracy. Clay Miner., 51(1), 1-17. doi.org/10.1180/clay$\min .2016 .051 .1 .01$

Tanit, C. and Arrykul, S. (2005). Compacted Sand-Bentonite Mixtures for Hydraulic Containment Liners. Songklanakarin J. Sci. Technol., 27(2), 313-323.

Taylor, R. and Allen, A. (2006). Waste disposal and landfill: information needs. In O. Schmoll, G. Howard, J. Chilton, I. Chorus: (Eds.) Protecting Groundwater for Health: Managing the Quality of Drinking-water Sources (pp. 339-362). London.

Teppen, B. J. and Miller, D. M. (2006). Hydration Energy Determines Isovalent Cation Exchange Selectivity by Clay Minerals. Soil Sci. Soc. Am. J., 70(1), 31. doi.org/10.2136/sssaj2004.0212.

Thornton, S. F., Bright, M. I., Lerner, D. N., Tellam, J. H. (2000). Attenuation of landfill leachate by UK Triassic sandstone aquifer materials 2. Sorption and degradation of organic pollutants in laboratory columns. J Contam Hydrol, 43(3-4), 355-383. doi.org/10.1016/s01697722(99)00105-9. 
Thornton, S. F., Bright, M. I., Lerner, D. N., Tellam, J. H., Scott, P. K. (1997). Laboratory studies of landfill leachate attenuation by clay liner materials. Proc. Sardinia 97, 6th Int. Landfill Symp. (T.H. Christensen, R. Cossu, R. Stegmann, eds), CISA-Environmental Sanitary Engineering Centre, Cagliari, Sardinia, 65-75.

Thornton, S. F., Lerner, D. N., Bright, M. L., Tellam, J. H. (1993). The Role of Attenuation in Landfill Liners. Proc. Sardinia 93, 4th Int. Landfill Symp. (T. H. Christensen, R. Cossu, R. Stegmann, eds), CISA-Environmental Sanitary Engineering Centre, Cagliari, Sardinia, 407-416.

Thornton, S. F., Lerner, D. N., Tellam, J. H. (2001). Attenuation of landfill leachate by clay liner materials in laboratory columns: 2 . Behaviour of inorganic contaminants. Waste Manag Res, 19(1), 70-88. doi. org/10.1177/0734242X0101900108.

Uma Shankar, M. and Muthukumar, M. (2017). Comprehensive review of geosynthetic clay liner and compacted clay liner. IOP Conference Series: Materials Science and Engineering, 263, 032026. doi. org/10.1088/1757-899X/263/3/032026.

Varghese, A. R. and Anjana, T. R. (2015). A Study on M-Sand Bentonite Mixture for Landfill Liners. Paper presented at the International Conference on Emerging Trends in Engineering \& Technology (ICETET-2015).

Wagner, J.F. (2013). Mechanical Properties of Clays and Clay Minerals. In F. B. G. Lagaly (Ed.), Developments in Clay Science (2nd ed., Vol. 5: Handbook of Clay Science. A: Fundamentals, pp. 347-381). The Netherlands: Elsevier.
Weaver, C. E. and Pollard, L. D. (1973). The Chemistry of Clay Minerals. Developments in Sedimentology (Vol. 15). Amsterdam, London, New York.: Elsevier Scientific Publishing Company.

Wei, Z., Shi, S., Shengwei, W., Haoqing, X., Xihui, F., Jianping, B., Fanlu, M. (2018). Patent. Municipal solid waste landfill barrier system capable of prolonging breakthrough time of leachate and manufacturing method thereof. US2018016766 (A1).

Widomski, M. K., Stepniewski, W., Horn, R. (2016). Sustainability of compacted clays as materials for municipal waste landfill liner. Rocznik Ochrona Srodowiska, 18, 439-454.

Widomski, M. K., Stepniewski, W., Musz-Pomorska, A. (2018). Clays of Different Plasticity as Materials for Landfill Liners in Rural Systems of Sustainable Waste Management. Sustainability, 10(7). doi. org/10.3390/su10072489

Yalcin, A. (2007). The effects of clay on landslides: A case study. Appl. Clay Sci., 38(1), 77-85. doi.org/10.1016/j.clay.2007.01.007.

Yesiller, N., Miller, C., Inci, G., Yaldo, K. (2000). Desiccation and Cracking Behavior of Three Compacted Landfill Liner Soils. Eng. Geol., 57(12), 105-121. doi.org/10.1016/S0013-7952(00)00022-3.

Zhao, Y., Hu, L., Cui, P., Hueckel, T. (2007). Evolution of shear strength of clayey soils in a landslide due to acid rain: A case study in the area of Three Gorges, China. Paper presented at the 1st North American Landslide Conference.

Zhan, T. L. T., Guan, C., Xie, H. J., Chen, Y. M. (2014). Vertical migration of leachate pollutants in clayey soils beneath an uncontrolled landfill at Huainan, China: A field and theoretical investigation. Sci. Total Environ, 470, 290-298. doi.org/10.1016/j.scitotenv.2013.09.081. 